\title{
Development and validation of a bovine macrophage specific cDNA microarray Kirsty Jensen ${ }^{* 1}$, Richard Talbot ${ }^{2}$, Edith Paxton ${ }^{1}$, David Waddington ${ }^{1}$ and Elizabeth J Glass ${ }^{1}$
}

\author{
Address: ${ }^{1}$ Division of Genetics \& Genomics, Roslin Institute, Roslin, Midlothian, Edinburgh, EH25 9PS, UK and ${ }^{2}$ ARK-Genomics Facility, Roslin \\ Institute, Roslin, Midlothian, Edinburgh, EH25 9PS, UK \\ Email: Kirsty Jensen* - Kirsty.Jensen@bbsrc.ac.uk; Richard Talbot - Richard.Talbot@bbsrc.ac.uk; Edith Paxton - Edith.Paxton@bbsrc.ac.uk; \\ David Waddington - Dave.Waddington@bbsrc.ac.uk; Elizabeth J Glass - Liz.Glass@bbsrc.ac.uk \\ * Corresponding author
}

Published: 0I September 2006

BMC Genomics 2006, 7:224 doi:10.1/86/|47|-2/64-7-224
Received: 26 May 2006

Accepted: 0 I September 2006

This article is available from: http://www.biomedcentral.com/I47/-2/64/7/224

(C) 2006 Jensen et al; licensee BioMed Central Ltd.

This is an Open Access article distributed under the terms of the Creative Commons Attribution License (http://creativecommons.org/licenses/by/2.0), which permits unrestricted use, distribution, and reproduction in any medium, provided the original work is properly cited.

\begin{abstract}
Background: The response of macrophages to danger signals is an important early stage in the immune response. Our understanding of this complex event has been furthered by microarray analysis, which allows the simultaneous investigation of the expression of large numbers of genes. However, the microarray resources available to study these events in livestock animals are limited.

Results: Here we report the development of a bovine macrophage specific (BoMP) cDNA microarray. The BoMP microarray contains 5026 sequence elements (printed in duplicate) and numerous controls. The majority of the clones incorporated on the microarray were derived from the BoMP cDNA library generated from bovine myeloid cells subjected to various stimuli, including over 900 sequences unique to the library. Additional clones representing immunologically important genes have been included on the BoMP microarray. The microarray was validated by investigating the response of bovine monocytes to stimulation with interferon- $\gamma$ and lipopolysaccharide using amplified RNA. At 2 and 16 hours post stimulation 695 genes exhibited statistically significant differential expression, including; 26 sequences unique to the BoMP library, interleukin 6, prion protein and toll-like receptor 4.
\end{abstract}

Conclusion: A $5 \mathrm{~K}$ cDNA microarray has been successfully developed to investigate gene expression in bovine myeloid cells. The BoMP microarray is available from the ARK-Genomics Centre for Functional Genomics in Farm Animals, UK.

\section{Background}

Macrophages $(\mathrm{m} \phi)$ play a key role in the immune system, acting as a bridge between the innate and adaptive immune responses. $M \phi$ are sentinel cells that instigate the removal of invading pathogens, either by phagocytosis or by signalling to other components of the immune system.
These signals include the release of various cytokines and the ability of $\mathrm{m} \phi$ to act as antigen-presenting cells.

$M \phi$ become activated when they interact with conserved, pathogen-specific stimuli, e.g. pathogen associated molecular patterns (PAMPs) such as lipopolysaccharide (LPS) and double-stranded RNA, characteristic of gram-negative 
Table I: Composition of the BoMP cDNA microarray.

\begin{tabular}{ll}
\hline BoMP cDNA library clones & \\
BLASTN hits & $2185(43.5 \%)$ \\
EST hits - bovine & human \\
other & $1139(22.7 \%)$ \\
Unique clusters & $156(3.1 \%)$ \\
ESTscans & $119(2.4 \%)$ \\
Unique singletons & $220(4.4 \%)$ \\
Additional clones & $174(3.5 \%)$ \\
MARCI-4/BARC5 & $592(11.8 \%)$ \\
Other libraries & \\
Amplicons & $355(7.1 \%)$ \\
Total & $26(0.5 \%)$ \\
\end{tabular}

The percentage of clones included on the BoMP microarray from various sources is listed along with the annotation available for the BoMP library clones.

bacterial or viral infections respectively. In addition cytokines, e.g. interferon- $\gamma$ (IFN- $\gamma$ ) produced by $\mathrm{T}$ lymphocytes and other immune cells, activate $\mathrm{m} \phi$. Activation results in extensive remodelling of the $\mathrm{m} \phi$ transcriptome, leading to morphological and physiological changes in the cell, including; alterations in shape, mobility and cell surface marker expression. These modifications equip the $\mathrm{m} \phi$ to deal effectively with the invading threat. However, many pathogens have evolved the ability to circumvent the action of $m \phi$ and several have developed the ability to exist undetected within the $m \phi$. These include a number of protozoan parasites including Leishmania species, Toxoplasma gondii and Theileria annulata $[1,2]$.

The complexity of the $\mathrm{m} \phi$ response to activation and infection is ideally suited for analysis by microarray technology, which allows the expression of thousands of genes to be investigated simultaneously. Numerous microarray experiments have now been published on the response of human and murine $\mathrm{m} \phi$ to a range of stimuli, including; various pathogens, PAMPs and cytokines [reviewed in [3]]. In contrast, only a handful of experiments have been reported for livestock species. For example, five publications have investigated the response of bovine $\mathrm{m} \phi$ and monocytes to stimuli [4-8]. Three of these studies have involved the use of commercially available human arrays. The most recent study used an in house bovine cDNA microarray [8], whilst the fifth study used a commercially available bovine array, which contains a limited number of immunologically important genes [6]. This partly results from an under-representation of immune genes in the EST datasets, caused by the generation of cDNA libraries from unactivated or uninfected immune tissue [9]. Although there are over 490,000 published bovine ESTs, IFN- $\gamma$ and interleukin-2 (IL2) are only represented by one and two bovine ESTs respectively, whilst no bovine ESTs have been published that represent IL4. This problem is not restricted to livestock species,
Wells and co-authors [10] have shown that $\mathrm{m} \phi$ transcripts are poorly represented within the RIKEN mouse EST set, one of the most extensive collections of mouse transcripts currently available $[11,12]$. Eighteen percent of clones from a murine $m \phi$ cDNA library were novel, failing to match any published sequences [10]. Similarly, we have recently reported the construction of a bovine $\mathrm{m} \phi$ (BoMP) specific cDNA library, in which over a third of clones appear to be novel, although this figure is decreasing as more bovine sequences become available [13]. The high percentage of novel sequences results from the inclusion of RNA samples in the library template that were collected from myeloid cells subjected to a range of different stimuli to maximize the number of transcripts associated with the immune response.

Here we report the use of BoMP library clones to construct a $5 \mathrm{~K}$ bovine macrophage specific (BoMP) cDNA microarray, which contains a large number of unique sequences. We also report the proof-of-principle experiment carried out using the BoMP microarray to investigate the response of bovine peripheral monocytes to LPS and IFN- $\gamma$ stimulation, which stimulate cellular pathways of importance in the in vivo inflammatory and infectious response of myeloid cells.

\section{Results \\ Characterization of the BoMP microarray}

In total the BoMP microarray comprises 5026 clones printed in duplicate and numerous controls. Over $52 \%$ of clones match annotated gene sequences, a further $28 \%$ match ESTs and the remaining clones are currently unique to the BoMP library (Table $1 \&$ Additional file 1). The majority of the clones were selected from the previously described BoMP cDNA library [13]. Approximately 10,000 clones from this library were considered for inclusion on the BoMP microarray. Clones that matched published sequences with $E$ values less than $e^{-20}$ were included on the microarray, including those that only matched EST sequences (3599 clones). In addition, a representative clone from each cluster of sequences unique to the BoMP library was included on the microarray (220 clones). The remaining sequences were analysed using ESTScan $[14,15]$, a web-based program that detects coding sequence by taking into account sequencing errors that frequently occur in single-pass sequences and can cause frame-shift mutations (174 clones). A further 592 unique BoMP clones were also randomly chosen for inclusion on the microarray.

T. annulata infected material was used to generate the BoMP library and as a result parasite sequence containing clones represent approximately $5 \%$ of the library [13]. Similarly, the infectious $T$. annulata sporozoites were prepared by homogenizing whole infected ticks, which has 
resulted in the presence of tick sequence containing clones in the library [13]. Eight clones known to contain nonbovine sequences have been included on the microarray; including C0006007g13 [EMBL: AJ817072] and C0006019k23 [EMBL: AJ820886], which match tick and parasite sequences respectively. These clones have been included as additional controls for a T. annulata infection experiment which will be reported elsewhere (Jensen et al., in prep.).

A number of immunologically important genes have not been detected in the BoMP library to date, partly because it has not been mined deeply. Therefore, a list of over 400 genes desirable for inclusion on the array was compiled. Where possible representative clones for these genes were selected for inclusion on the microarray from the various libraries housed at the ARK-Genomics facility (381 clones). The majority of these clones came from the Meat Animal Research Centre (MARC) and Beltsville Agricultural Research Centre (BARC) libraries MARC 1-4 BOV and BARC 5 BOV $[16,17]$, e.g. macrophage migration inhibition factor (MIF) and integrin beta 6 . Clones were not available for 60 genes on our compiled list. Therefore we generated amplicons for each of these clones using publicly available sequence information to design oligonucleotides suitable for amplification, e.g. IL6, caspase 3 (CASP3) and Toll-like receptor 9 (TLR9) (Table 2).

The BoMP microarray has been constructed at the ARKGenomics Centre for Functional Genomics in Farm Animals [18] and submitted to ArrayExpress as ARK-Genomics Bovine Macrophage Specific-BoMP-cDNA microarray $5 \mathrm{~K}$ v1.0 and has the accession number A-MEXP-495 $[19,20]$.

\section{Analysis of microarray quality}

Five randomly selected microarray slides from the print run were hybridized with Panomer 9 oligonucleotides (Molecular Probes). This hybridization visualized the size and shape of all printed spots, which allowed us to ensure uniformity in the amount of DNA spotted by each pin and to check the integrity of each spot. This test hybridization confirmed that the microarray printing had been successful (data not shown).

Normalized data from the experiment described below was used to investigate the consistency of the intensity measurements for replicate spots. The contributions of slide, gene, replicate spots and channel to the variability of the logarithm of the intensities were assessed by fitting them as random effects in a linear model. The fixed effects of animal and time were also included in the model. Intensity differences between genes were the largest contributor, accounting for $79 \%$ of the variation (Table 3, variance \%). Almost all the remaining variation was accounted for equally between replicate spots and between channels, leaving little contribution from slides. Therefore, approximately $80 \%$ of the overall measured variation was of biological rather than technical origin. This summary is an oversimplification, which is illustrated by the variation observed in values when the time points are examined separately (Table 3, last 6 columns) and results from the failure to allow for the effects of differentially expressed genes in the 2 and 16 hour samples. The results for the 0 hour samples would be expected to be similar to that from a self-self hybridization and they do show more agreement that the other time points. The correlations between channel $\log$ (intensities) for the 0,2 and 16 hour time points were $0.95,0.89$ and 0.88 respectively (calculated as (100-channel\%)/100 from the last 3 columns of Table 3 ).

\section{Microarray analysis of monocyte activation}

As a further evaluation of the BoMP microarray, it was used to investigate the response of bovine peripheral monocytes to stimulation. As part of a larger experiment, peripheral monocytes were isolated from six HolsteinFriesians under cold conditions before stimulation with LPS and IFN- $\gamma$. RNA was isolated from the cells of each animal at 0,2 and 16 hours post activation. The quantity of total RNA (totRNA) isolated from these cells was too low for direct use in microarray experiments and therefore amplified RNA (aRNA) was generated.

The parameters used to identify genes exhibiting statistically significant differences in gene expression during the time course were a 2 fold or greater change in gene expression and a false discovery rate value (FDRmax) less than 0.01 . Using these criteria 713 clones exhibited statistically significant changes in gene expression during the time course. Several of these clones represented the same gene and therefore a total of 695 genes exhibited differential expression (Additional file 2). Twenty-six of these were sequences unique to the BoMP library [13]. These included C0006011i04 [EMBL: AJ818203] that was upregulated 8.4 fold by 16 hours post activation and

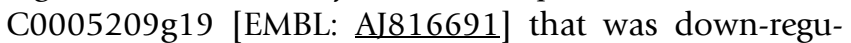
lated 13.2 fold by 16 hours post activation. A further 171 sequences that exhibit differential expression currently only match ESTs. Putative gene names have been assigned to the remaining 498 sequences. The gene ontology information that is available for 398 of these genes illustrates the broad range of biological processes affected by activation with LPS and IFN- $\gamma$, including; signal transduction, transcription, immune response, apoptosis, cell proliferation, metabolism, intracellular transport, translation and proteolysis. Furthermore, 190 of the genes have been incorporated into KEGG pathways, with the largest number of genes being involved in cytokine-cytokine receptor interactions, haematopoietic cell lineage, TLR sig- 
Table 2: Amplicons generated to represent 60 immunologically important genes.

\begin{tabular}{|c|c|c|c|c|c|}
\hline Gene & Symbol & Accession No. & Size (bp) & Forward Primer 5'-3' sequence & Reverse Primer 5'-3' sequence \\
\hline Annexin-A5 & ANXA5 & $\underline{\mathrm{CO} 883855}$ & 700 & ATG GCA CAG GTT CTC AGA GG & CCA AAT TGC CAG AAG TCT CC \\
\hline Baculoviral IAP-repeat containing 5 & BIRC5 & $\overline{B E 486047}$ & 451 & CCT GGC AGC TCT ACC TCA AG & CCC TGG AAA CGA CGT GTC TG \\
\hline B-cell CLL/lymphoma 3 & $\mathrm{BCL3}$ & CK771977 & 537 & CTT CTT GGC ACT CGG TGT TC & GAC CAG AGG CAA TTT ACT ACC \\
\hline Capping protein (actin filament) gelsolin like & CAPG & AY219899 & 615 & TAT GGA GGG TGG AGA AGC TG & TGG GAC CCA AGA CCT GTA TC \\
\hline Casein kinase II $\alpha$ l & CSNK2AI & $\times 54962$ & 405 & GTT AAT ACA CAC AGA CCC CGA & GCT ATG GCA GTA ATC AAG GGC C \\
\hline Caspase 3 & CASP3 & CK958902 & 679 & GTG GAT GCA GCA AAC CTC AG & CCA TTT GCT CAC TTG GCA TAC \\
\hline Caspase 7 & CASP7 & $\overline{\mathrm{CK} 436554}$ & 549 & TCT TCC AAA GTC ACC ACC AG & GGA GTG GCT CTT GGT TTG TG \\
\hline Caspase recruitment domain family member 4 & CARD4 & $\overline{\mathrm{CO} 0886987}$ & 630 & ATG TCG GAG CCA GGT ACA TC & GAA GTC CCA CCT CAG CAG AC \\
\hline CD2 antigen & $\mathrm{CD} 2$ & CN789613 & 544 & CAG AAC TGT GAG CTG CAA GG & TTG CTG GTG AAC TTG TGT GC \\
\hline CD3 antigen $\gamma$ & CD3G & $\overline{\text { CD445323 }}$ & 518 & GAA GGA GTT CGC CAG TCA AG & TGA TGA GAA TAG CCA ATA AGC AC \\
\hline CD40 ligand & CD40LG & $\underline{Z 48469}$ & 652 & TAA CGC AGC ATG ATC GAA AC & AGA ACT GTG GGT GTT TGC AG \\
\hline CD63 antigen & CD63 & $\overline{\mathrm{A} J 012589}$ & 606 & TTC TCC TGC TGG TCT TCT GC & GGA TCT CCA CAA AGG CAA TG \\
\hline CD80 antigen & CD80 & $\overrightarrow{\mathrm{BF} 039039}$ & 522 & GGT ACT CCA ACC AGC GTC TC & AGG TGT AGG TGC CAC TGT CC \\
\hline CD86 antigen & CD86 & A) 291475 & 674 & GCC TTC TTC AAC GAG ACT GG & GCA ATC CAG AGG ATG TGG TC \\
\hline CD200 receptor I & CD200RI & CK831048 & 552 & CTG TGG ACA GAA AGC AGA GC & GGT TCT GAC ACC TTT ATC CAG \\
\hline Chemokine ( $\mathrm{C}$ motif) ligand I & XCLI & AF354057 & 411 & TCA GCC TCT TAC TGC ACA GC & AAA TGA GGT GGC TGG CTA GG \\
\hline Chemokine (C-C motif) ligand 8 & CCL8 & $\underline{\mathbf{S 6 7 9 5 4}}$ & 667 & TGA GAC CAA CTC AGC AAT CG & AGT GGA AGG ACC TCA CCA TC \\
\hline Colony stimulating factor 2 & CSF2 & $\underline{\mathrm{U} 22385}$ & 602 & GAG GAT GTG GCT GCA GAA CC & CCT GTA TCA GGG TCA ACA TGG \\
\hline Colony stimulating factor 2 receptor $\alpha$ & CSF2RA & $\overline{\mathrm{BE} 480577}$ & 455 & CCA AAT GCC AGC CTA AAT GTG & CGA GAG GTC TTG GAG GTG AC \\
\hline Complement component 5 receptor I & C5RI & $\times \underline{X 5861}$ & 396 & ATC ATC CAG CAC AAC CAC TG & GCA GGA GGA AGG TGT AAC AG \\
\hline FcyRl $\alpha(C D 64)$ & FCGRIA & $\mathrm{AFI62866}$ & 630 & TCT GGT CAA CCT GAG CTG TG & TAA GAT GCC AAG GGA GTT GC \\
\hline FcyRIIIb (CDI6b) & FCGR3B & $\overline{\mathrm{AFI}} 32036$ & 502 & CTT TCA GCT GAC ACG CAA AC & TTT CCT GCT GCT CCC AGA G \\
\hline $\begin{array}{l}\text { Inhibitor of kappa light polypeptide gene enhancer in } \\
\text { B-cells, kinase } \beta\end{array}$ & IKBKB & A]414556 & 688 & TTT GAC AAC AGC AGG GTC AC & TGC AGA CCA CGG TCT TAC TG \\
\hline $\begin{array}{l}\text { Inhibitor of kappa light polypeptide gene enhancer in } \\
\text { B-cells, kinase } \gamma\end{array}$ & IKBKG & A) 414557 & 694 & ATG GAG TGC ATC GAG TAG GG & AGA GAG GAG CTC ACC TTG TG \\
\hline Insulin-like growth factor I & IGFI & $\times 15726$ & 661 & GTG ATC TGA GGA GGC TGG AG & AGG TGA TGG AGA AGG GAG TG \\
\hline Integrin $\alpha \mathrm{V}$ (CD5I) & ITGAV & $\mathrm{BM431105}$ & 505 & CAT ATC TGC GGG ATG AAT CTG & TCC ATC TCT GAT TGC TGG TG \\
\hline Integrin $\alpha 6$ (CD49f) & ITGA6 & CK970520 & 554 & TAC CCT GAT GTT GCT GTT GG & ATG TTG TCG TCT CCA CAT CC \\
\hline Integrin $\beta$ I (CD29) & ITGBI & AF468058 & 691 & TGT GTT TCA CTT CGC TGG AG & TTC GCT GTT CAC CTC ATC TG \\
\hline Integrin $\beta 3$ (CD6I) & ITGB3 & $\overline{\mathrm{CN} 79 \mid 459}$ & 530 & TGT TCT CCA GCT CAT TGT GG & TCT TGC CAA AGT CAC TGC TG \\
\hline Intercellular adhesion molecule (CD50) & ICAM3 & $\underline{L 41844}$ & 628 & CCA AGA GAT TGT CTG CAA CG & GCC CAA GAT CGC TAA CAC TC \\
\hline Interferon $\alpha$ & IFNA & $\overline{Z 46508}$ & 439 & GGT CCT GAT GCT CCT GAG AC & CCT GCA AGT TTG TTG AGG AAG \\
\hline Interferon $\beta$ | & IFNBI & $\overline{M 15477}$ & 568 & TCT CCA CCA CAG CTC TTT CC & TCT CAC CTC AAA GTC ACA TTG \\
\hline Interferon $\gamma$ & IFNG & M39867 & 561 & GGA GCT ACC GAT TTC AAC TAC TCC G & GCA GGC AGG AGG ACC ATT ACG \\
\hline Interferon regulatory factor 2 & IRF2 & A]490936 & 686 & AAA CTG GGC CAT CCA TAC AG & TGT TGG ACG TGA CAA AGG TG \\
\hline Interleukin I $\beta$ & ILIB & M3721I & 699 & AAG GCT CTC CAC СTC CTC TC & TGG TTG CTC ATC AGA AGC TG \\
\hline Interleukin I receptor-associated kinase I & IRAKI & BG692698 & 405 & СTC TCT CCT GGC CTC AGC & CTT CCG CCT ССТ СТT CAA C \\
\hline Interleukin 2 & IL2 & MI3204 & 498 & GGT CGT TCA TGT CAG CAA TG & GAG GCA CTT AGT GAT CAA GTC \\
\hline Interleukin 4 & IL4 & $\overline{M 77120}$ & 451 & GCA TTG TTA GCG TCT CCT GGT AAA C & СTT CAT AAT CGT CTT TAG CCT TTC C \\
\hline Interleukin 6 & IL6 & $\underline{\times 57317}$ & 620 & ATG AAC TCC CGC TTC ACA AGC & TAC TTC ATC CGA ATA GCT CTC \\
\hline Interleukin 8 & IL8 & $\overline{\mathrm{AF} 232704}$ & 660 & CAG CAG AGC TCA CAA GCA TC & AAA AGC AGG ATT TCC AGA TCG \\
\hline Interleukin I2A & ILI2A & $\underline{U 14416}$ & 350 & CAG CAA CAC GCT ACA GAA GG & CCT GCA TCA GCT CAG CAA TA \\
\hline Interleukin I2B & ILI $2 B$ & $\overline{\mathrm{U} 11815}$ & 553 & CCT GTC ACA AAG GAG GCG AGG C & CGT CAG GGA GAA GTA GGA ATG CGG \\
\hline
\end{tabular}


Table 2: Amplicons generated to represent 60 immunologically important genes. (Continued)

\begin{tabular}{|c|c|c|c|c|c|}
\hline Interleukin 13 & IL13 & CB454692 & 477 & CCT CAA TTT CTT CCT GTG CTG & ATG GTC AGG ATC TGC CTC TG \\
\hline Interleukin 15 & ILI5 & $\underline{\mathrm{U} 42433}$ & 323 & ATC CAG TGC TAC TTG TGT TTA C & GCT GTT TGC TAG CAT GGT AAG \\
\hline MHC class II DYA & $\begin{array}{l}\text { BOLA- } \\
\text { DYA }\end{array}$ & A]580583 & 623 & ACC ACT TGG AAC AGC CAC TC & CAG TGC TCC ACT CTG CAG TC \\
\hline Myeloid differentiation primary response gene & MYD88 & A]634627 & 431 & GTG GTG GTG GTC TCT GAC G & GTG CCA CGT GTT CTA TGC AG \\
\hline $\begin{array}{l}\text { Nuclear factor of kappa light polypeptide gene } \\
\text { enhancer in B-cells } 2 \text { (p49/p 100) }\end{array}$ & NFKB2 & $\underline{\mathrm{CO} 259349}$ & 411 & GGC TAT ACC CAG TCC ACC TG & TGA GGT CAA GAG GTG TGT GG \\
\hline Prostaglandin-endoperoxide synthase 2 & PTGS2 & AF031698 & 651 & CCA GAG CTC TTC CTC CTG TG & GCA GCT CTG GGT CAA ACT TC \\
\hline Selectin P ligand (CDI62) & SELPLG & BF654668 & 421 & ACC ATC TTC CTC GTG TGC AC & CTA CCG GAG GTT CTG TTT GC \\
\hline SH3-domain kinase binding protein I & SH3KBPI & A/819523 & 340 & GTC AGG GCT TGA AAG GGA AG & GCC TTC TGT TCC TGC CAT AC \\
\hline Signal transducer \& activator or transcription I & STATI & BE588937 & 519 & GCG AGT CAG ATC CAA GAT AG & ATC CTG AAG GTT ACG CTT GC \\
\hline Tissue inhibitor of metalloproteinase 2 & TIMP2 & $\underline{\mathrm{M} 32303}$ & 617 & GGG CCA AAG CAG TCA ATA AG & TTC ATG CTG TGT CCA GGA AG \\
\hline Toll-like receptor 7 & TLR7 & AY487802 & 693 & GCC TTC TGA TTT CCA GCA TC & TTT GTC AGG CAC CTG ATT TG \\
\hline Toll-like receptor 8 & TLR8 & AY642125 & 362 & GGT GAT GAA TGA GCT GCG C & CTT TGC CAA AAC AAG CCC TC \\
\hline Toll-like receptor 9 & TLR9 & Al509825 & 694 & TCA CCA GCC TCT ССТ TAA TCT C & GAG AGA ACT GTC CTT CAA CAC C \\
\hline Transforming growth factor $\beta$ I & TGFBI & M3627I & 668 & GCC ATA CTG GCC CTT TAC AA & GCT GAC GAA CAC AGC AGT TC \\
\hline Transforming growth factor $\beta 3$ & TGFB3 & CA034974 & 374 & AGG TGT GGA AAT CAG CAT CC & CTG AGC AGA AGT TGG CAT AG \\
\hline Transforming growth factor $\beta$ receptor II & TGFBR2 & CK772005 & 701 & GTG TTG AGG GAG CCA TCT TC & AAC CTG CAG GAG TAC CTG AC \\
\hline Tumour necrosis factor $\alpha$ & TNF & AFOII926 & 660 & AGC TGG CGG AGG AGG TGC TC & $\begin{array}{l}\text { CAG GGC GAT GAT CCC AAA GTA GAC } \\
\text { C }\end{array}$ \\
\hline TNFRSF6 (fas) & FAS & $\underline{\text { U34794 }}$ & 645 & TTC GGA AGA ACG GTA TGG AG & CCT GTG GAT AGG CAT GTG TG \\
\hline
\end{tabular}

List of the genes chosen for amplicon construction. The sequences used to design the primers and the sizes of the clone inserts are listed. 
Table 3: Factors affecting intensity measurements.

\begin{tabular}{lcccccccccc}
\hline Effect & Variance & SE (variance) & Variance \% & $\begin{array}{c}\text { Variance 0 } \\
\text { hours }\end{array}$ & $\begin{array}{c}\text { Variance 2 } \\
\text { hours }\end{array}$ & $\begin{array}{c}\text { Variance 16 } \\
\text { hours }\end{array}$ & $\begin{array}{c}\text { Variance 0 } \\
\text { hours (\%) }\end{array}$ & $\begin{array}{c}\text { Variance 2 } \\
\text { hours (\%) }\end{array}$ & $\begin{array}{c}\text { Variance 16 } \\
\text { hours (\%) }\end{array}$ \\
\hline Slide & 0.032 & 0.015 & 2 & 0.035 & 0.161 & 0.054 & 2 & 10 & 4 \\
Gene & 1.146 & 0.006 & 79 & 1.126 & 1.152 & 1.160 & 80 & 71 & 77 \\
Replicate Spots & 0.135 & 0.001 & 9 & 0.174 & 0.123 & 0.107 & 12 & 8 & 7 & 11 \\
Channel & 0.145 & 0.001 & 10 & 0.069 & 0.179 & 0.186 & 5 & 12 \\
\hline
\end{tabular}

The contributions to variation in log(intensity) of slide, gene, replicate spots and channel, together with their standard errors and percentage variance accounted for. Equivalent estimates and percentages are presented separately for the 3 time points

nalling, mitogen activated protein kinase (MAPK) signalling, Jak-STAT signalling, apoptosis, focal adhesion, complement and coagulation cascade, regulation of actin cytoskeleton and calcium signalling.

The limited number of time points sampled in this experiment restricts the information that can be obtained from cluster analysis. However, the 695 genes can be separated into groups exhibiting 8 broad expression patterns. The genes up-regulated at 2 hours fall into 3 groups; those that remain up-regulated (133 genes) including chemokine (C-C motif) ligand 2 (CCL2) and prion protein, those that return to resting levels (132 genes) including v-rel reticuloendotheliosis viral oncogene homolog (REL) and finally TIMP metallopeptidase inhibitor 1 (TIMP1) that is down-regulated beyond the resting state level. The genes down-regulated at 2 hour post activation can be grouped in a similar manner; those that remain down-regulated (48 genes) including v-fos FBJ murine osteosarcoma viral oncogene (FOS), those that return to resting levels (114 genes) including chemokine (C-C motif) receptor 2 (CCR2) and finally C0006007114 [EMBL: AJ817952] which is up-regulated above the resting state level. The remaining genes exhibit a delayed alteration in expression that was observed only at 16 hours, and were either upregulated (110 genes) e.g. fibronectin 1 (FN1) or downregulated (151 genes) e.g. CD86 antigen.

Eighteen differentially expressed genes are represented by more than one clone. The duplicate clones of 13 of these genes are grouped together by expression pattern, e.g. FN1 and CCR1. The duplicate clones for the remaining 5 genes, e.g. IL12A, fall into different groups. Further analysis shows that the duplicate clones exhibit similar hybridization patterns, but the differential expression detected by one clone lies outside the threshold criteria used to identify differentially expressed genes.

\section{2 hours post LPS \& IFN- $\gamma$ stimulation}

A total of 444 genes exhibited differential expression in monocytes at 2 hours post activation compared to resting monocytes ( $\geq 2$ fold, FDRmax $\leq 0.01$ ). Of these 279 were up-regulated and the top 25 genes exhibiting greatest upregulation are listed in Table 4 . Eight of these are chemok- ines, including IL8 and CCL2. Interestingly the prion protein was up-regulated on average 28.1 fold after 2 hours activation. Three of the most up-regulated genes are only represented by ESTs.

A further 165 genes are down-regulated 2 hours post activation compared to resting cells and the top 25 genes are listed in Table 5. These include IL16, CCR2 and MAPK14. Several of the most down-regulated genes are transcription factors, e.g. CCCTC-binding factor (CTCF), TAF7 RNA polymerase II, TATA box binding protein-associated factor (TAF7) and nuclear factor (erythroid-derived 2) (NFE2).

\section{6 hours post LPS \& IFN- $\gamma$ stimulation}

A total of 457 genes exhibit differential expression in monocytes at 16 hours post activation compared to resting monocytes $(\geq 2$ fold, FDRmax $\leq 0.01$ ). Of these 253 are up-regulated and the top 25 genes exhibiting greatest up-regulation are listed in Table 6 . There is considerable overlap between the top 25 genes up-regulated at 2 and 16 hours post activation, including IL8 and prion protein. Other up-regulated genes include IL1 $\beta$, IL2 receptor $\beta$ chain (IL2RB) and actinin $\alpha 1$.

A further 204 genes are down-regulated at 16 hours post activation and the top 25 genes are listed in Table 7 . These include the previously mentioned unique sequence C0005209g19 [EMBL: AJ816691] and five sequences that only match ESTs. Two ribonucleases are down-regulated, as well as cell surface receptors; IL6 receptor (IL6R), mannose receptor, $\mathrm{C}$ type 1-like 1 (MRC1L1) and CD59. Only 2 genes are found in the top 25 down-regulated genes at 2 and 16 hours post activation; IL16 and chromosome 6 open reading frame 32 (C6orf32) protein.

\section{Validation of microarray results}

To validate the results from the microarray experiment, thirty genes were chosen for reverse transcriptionpolymerase chain reaction (RT-PCR) analysis. The mRNA levels of all thirty appeared to follow the same pattern as seen on the microarray (data not shown). The correct identification of the representative clones for these 30 genes was confirmed by sequence analysis (data not 
Table 4: The top 25 genes exhibiting increased mRNA abundance 2 hours post activation.

\begin{tabular}{|c|c|c|c|c|c|c|c|}
\hline Clone & E value & Accession No. & Gene Symbol & Gene & Fold Increase & FDRmax & $P$ value \\
\hline plL8 & 0.0 & NM 173925 & IL8 & Interleukin 8 & 40.00 & $1.23 \mathrm{E}-18$ & 4.9IE-22 \\
\hline MARC_3BOV_60PI7 & 0.0 & NM 174299 & CXCL2 & $\begin{array}{l}\text { Chemokine (C-X-C motif) ligand } 2 \\
\text { (GRO } \beta / M I P 2 A)\end{array}$ & 38.20 & $1.25 \mathrm{E}-15$ & $1.24 \mathrm{E}-18$ \\
\hline $\mathrm{C} 0006019 \mathrm{e} 20$ & 0.0 & NM 181015 & PRNP & Prion protein & 28.13 & I.05E-20 & $2.08 \mathrm{E}-24$ \\
\hline MARC_IBOV_IOIM3 & 0.0 & NM 174263 & CCL20 & $\begin{array}{l}\text { Chemokine (C-C motif) ligand } 20 \\
\text { (MIP3A) }\end{array}$ & 25.81 & 3.14E-10 & $3.56 \mathrm{E}-12$ \\
\hline MARC_IBOV_94L3 & 0.0 & NM 174300 & CXCL6 & Chemokine (C-X-C motif) ligand 6 & 22.91 & I.72E-II & $1.23 \mathrm{E}-13$ \\
\hline $\mathrm{C} 0005209 \mathrm{~b} 8$ & $6.00 \mathrm{E}-72$ & $\underline{X M ~ 612426}$ & CCRN4L & $\begin{array}{l}\text { CCR4 carbon catabolite repression } \\
\text { 4-like }\end{array}$ & 20.49 & I.64E-II & $1.14 \mathrm{E}-13$ \\
\hline C00060I8nI4 & 0.0 & NM 174006 & CCL2 & $\begin{array}{l}\text { Chemokine (C-C motif) ligand } 2 \\
\text { (MCP-I) }\end{array}$ & 19.45 & I.32E-07 & 4. $19 \mathrm{E}-09$ \\
\hline C0005204j 16 & 0.0 & $\underline{X M 864683}$ & $\mathrm{CXCL3}$ & $\begin{array}{l}\text { Chemokine (C-X-C motif) ligand } 3 \\
\text { (GRO } / \text { MIP2b) }\end{array}$ & 18.16 & I.20E-13 & $3.40 \mathrm{E}-16$ \\
\hline C0006020dII & 0.0 & $\underline{X M} 865242$ & ZFAND2A & Zinc finger, ANI-type domain $2 \mathrm{~A}$ & $|7.6|$ & I.10E-14 & $1.31 \mathrm{IE}-17$ \\
\hline C00060Ilel3 & e-179 & CK976904 & - & EST & $16.7 \mid$ & 3. $10 \mathrm{E}-08$ & $8.4 I E-10$ \\
\hline C0005208k22 & e- 167 & NM 173198 & NR4A3 & $\begin{array}{l}\text { Nuclear receptor subfamily } 4 \text {, group } \\
\text { A, member } 3\end{array}$ & 15.65 & $2.39 \mathrm{E}-12$ & I. $14 \mathrm{E}-14$ \\
\hline $\mathrm{C} 0006020 \mathrm{e} 20$ & 0.0 & $\underline{\text { CB419326 }}$ & - & EST & 14.07 & $9.10 \mathrm{E}-12$ & $5.60 \mathrm{E}-14$ \\
\hline MARC_3BOV_36F6 & 0.0 & NM 175827 & CCL5 & $\begin{array}{l}\text { Chemokine (C-C motif) ligand } 5 \\
\text { (RANTES) }\end{array}$ & 13.84 & $2.90 \mathrm{E}-12$ & $1.47 \mathrm{E}-14$ \\
\hline C00060I8g13 & 0.0 & $\underline{X M} 611249$ & SLCO4AI & $\begin{array}{l}\text { Solute carrier organic anion } \\
\text { transporter family, member } 4 \mathrm{Al}\end{array}$ & 13.79 & $4.62 \mathrm{E}-10$ & $5.89 \mathrm{E}-12$ \\
\hline MARC_IBOV_72MI2 & 0.0 & $\underline{X M ~ 866821}$ & CXCLIO & $\begin{array}{l}\text { Chemokine (C-X-C motif) ligand } 10 \\
\text { (IPI0) }\end{array}$ & |3.7| & I.09E-05 & 6.09E-07 \\
\hline $\mathrm{C} 0005199 \mathrm{cl} 3$ & 0.0 & AY248754 & TNFAIP3 & TNF-alpha induced protein 3 & 13.48 & 2.34E-08 & $5.90 \mathrm{E}-10$ \\
\hline C00060I5ell & 0.0 & $\underline{X M 881561}$ & PMAIPI & $\begin{array}{l}\text { Phorbol-12-myristate-13-acetate- } \\
\text { induced protein I }\end{array}$ & 12.99 & $1.95 \mathrm{E}-12$ & $8.90 \mathrm{E}-15$ \\
\hline C0005202i8 & 0.0 & $\underline{\text { XM } 583725}$ & АРОВЕСЗА & $\begin{array}{l}\text { Apolipoprotein B mRNA editing } \\
\text { enzyme, catalytic polypeptide-like } 3 \mathrm{~A}\end{array}$ & 12.96 & $1.20 \mathrm{E}-13$ & $2.97 \mathrm{E}-16$ \\
\hline MARC_3BOV_I20N2I & 0.0 & NM 174028 & CSF3 & $\begin{array}{l}\text { Colony stimulating factor } 3 \\
\text { (granulocyte) (G-CSF) }\end{array}$ & 12.76 & 8.IIE-II & $7.73 \mathrm{E}-13$ \\
\hline C00060I5nI5 & $2.00 \mathrm{E}-69$ & NM 002748 & MAPK6 & $\begin{array}{l}\text { Mitogen-activated protein kinase } 6 \\
\text { (erk-3) }\end{array}$ & 12.64 & $8.88 \mathrm{E}-12$ & 5.IIE-I4 \\
\hline $\mathrm{C} 0006016 \mathrm{hl} 5$ & 0.0 & $\underline{X M} 613370$ & RGSI & Regulator of G-protein signalling I & 12.59 & 5.10E-09 & $1.00 \mathrm{E}-10$ \\
\hline C00060I3pI5 & e- 158 & CB534198 & - & EST & 12.59 & $1.93 \mathrm{E}-11$ & $1.50 \mathrm{E}-13$ \\
\hline C0005202d9 & 0.0 & XM 870158 & ANKRD22 & Ankyrin repeat domain 22 & 11.99 & $6.36 \mathrm{E}-17$ & $3.79 \mathrm{E}-20$ \\
\hline MARC_IBOV_57BI2 & 0.0 & NM 174348 & ICAMI & $\begin{array}{l}\text { Intercellular adhesion molecule I } \\
\text { (CD54) }\end{array}$ & 11.40 & $6.40 \mathrm{E}-10$ & $9.15 \mathrm{E}-12$ \\
\hline C0005206b23 & $3.00 \mathrm{E}-82$ & NM 001432 & EREG & Epiregulin & 10.98 & I.98E-07 & 6.6IE-09 \\
\hline
\end{tabular}

Summary of the top 25 genes exhibiting increased mRNA abundance 2 hours post activation, including clone name, accession number, e-value and identity of the best BLAST match and average fold change. The $P$ and FDRmax values denote the probability from the moderated t-test and the Benjamini and Hochberg false discovery rate values respectively from the analysis of the resting cell values compared to the average activated sample values (Pre v Post).

shown). Ten of these genes were selected for further quantitative RT-PCR (qRT-PCR) analysis to verify the abundance of mRNA present in the original totRNA samples from the six Holstein-Friesians used to generate the aRNA for the microarray experiment (Table 8). These genes were chosen because they displayed a range of differential expression during the time course. CCL2, prion protein and IL6 were highly up-regulated during the experiment, whilst FOS was down-regulated. FN1, CCR1 and complement component 1 , $r$ subcomponent $(\mathrm{C} 1 \mathrm{R})$ were up-regulated by 16 hours post activation, whilst CD86 was down-regulated by this time-point. CD9 and CD44 did not differ significantly during the time course.
The correspondence between the qRT-PCR and microarray expression measurements is shown in Figure 1. There is good agreement between the average $\log$ (fold changes) for the 10 genes, with an overall correlation of 0.78 (Figure 1A). The means for 6 genes; C1R, CCR1, CD86, FN1, FOS \& PRNP, lie close to the line of equality. CD9 and CD44 exhibit 2-3 times higher fold changes by qRT-PCR than by microarray analysis and CCL2 results are 5 and 13 times greater. The fold change was dramatically different for IL6, being 70 and 130 times greater by qRT-PCR analysis than microarray analysis. The correlation between the qRT-PCR and microarray data was further investigated by comparing the results for individual animals. The individ- 
Table 5: The top 25 genes exhibiting decreased mRNA abundance 2 hours post activation.

\begin{tabular}{|c|c|c|c|c|c|c|c|}
\hline Clone & Evalue & Accession No. & Gene Symbol & Gene & Fold Decrease & FDRmax & $P$ value \\
\hline $\mathrm{C} 0006018 \mathrm{hl} 6$ & 0.0 & NM 031483 & $\mathrm{ITCH}$ & $\begin{array}{l}\text { Itchy homolog E3 ubiquitin protein } \\
\text { ligase }\end{array}$ & -5.36 & $2.55 \mathrm{E}-10$ & $2.79 \mathrm{E}-12$ \\
\hline MARC_2BOV_I4NI3 & e-|5| & $\underline{X M ~} 582744$ & ILI6 & Interleukin 16 & -4.94 & $9.35 \mathrm{E}-10$ & I.4IE-II \\
\hline C00060IIpI5 & 0.0 & NM 003400 & XPOI & Exportin I & -4.11 & $3.28 \mathrm{E}-03$ & 4.70E-04 \\
\hline C00060IId04 & $e-112$ & NM 000199 & SGSH & $\mathrm{N}$-sulfoglucosamine sulfohydrolase & -4.05 & 4.14E-05 & $2.88 \mathrm{E}-06$ \\
\hline C0005202bll & 0.0 & NM 006565 & CTCF & СССТC-binding factor & -3.83 & $9.04 \mathrm{E}-06$ & 4.90E-07 \\
\hline C00060I4p20 & 0.0 & NM 005642 & TAF7 & $\begin{array}{l}\text { TAF7 RNA polymerase II, TATA } \\
\text { box binding protein (TBP)- } \\
\text { associated factor, } 55 \mathrm{kDa}\end{array}$ & -3.74 & 7.65E-09 & $1.6 \mathrm{IE}-10$ \\
\hline MARC_IBOV_I07K4 & 0.0 & $\underline{X M 584158}$ & CCR2 & Chemokine (C-C motif) receptor 2 & -3.70 & 4.8IE-06 & $2.40 \mathrm{E}-07$ \\
\hline C0005203a5 & $6.00 \mathrm{E}-54$ & NM 032804 & Cl0orf22 & $\begin{array}{l}\text { Chromosome } 10 \text { open reading } \\
\text { frame } 22\end{array}$ & -3.69 & 2.77E-04 & $2.68 \mathrm{E}-05$ \\
\hline $\mathrm{C} 0006005 \mathrm{~d} 04$ & 0.0 & $\underline{X M ~} 588702$ & UNG & Uracil-DNA glycosylase & -3.62 & $4.24 \mathrm{E}-10$ & $5.00 \mathrm{E}-12$ \\
\hline C0007385DI8 & 0.0 & $\underline{B M 087483}$ & - & EST & -3.60 & 2.00E-03 & $2.63 \mathrm{E}-04$ \\
\hline C0006007o03 & e-153 & NM 016046 & EXOSCI & Exosome component I & -3.51 & 6.69E-07 & 2.57E-08 \\
\hline $\mathrm{C} 0006019 \mathrm{~m} 08$ & 0.0 & $\underline{X M 868169}$ & - & Hypothetical protein LOC616204 & -3.51 & 8.67E-06 & 4.67E-07 \\
\hline C0005205c2 & $2.00 \mathrm{E}-70$ & NM 024939 & RBM35B & RNA binding motif protein 35B & -3.50 & $7.22 \mathrm{E}-08$ & 2.15E-09 \\
\hline $\mathrm{C} 0005207 d 22$ & 0.0 & NM 013444 & UBQLN2 & Ubiquilin 2 & -3.48 & I.36E-08 & $3.13 \mathrm{E}-10$ \\
\hline C0005I98j2 & $7.00 \mathrm{E}-58$ & NM 139014 & MAPKI4 & $\begin{array}{l}\text { Mitogen-activated protein kinase } \\
14(\mathrm{p} 38)\end{array}$ & -3.41 & I.36E-08 & $3.15 \mathrm{E}-10$ \\
\hline C0006005h08 & 0.0 & NM 052911 & ESCOI & $\begin{array}{l}\text { Establishment of cohesion I } \\
\text { homolog I }\end{array}$ & -3.36 & $9.89 \mathrm{E}-06$ & $5.48 \mathrm{E}-07$ \\
\hline C0005202116 & $4.00 \mathrm{E}-42$ & $\underline{X M ~} 545369$ & C6orf32 & $\begin{array}{l}\text { Chromosome } 6 \text { open reading } \\
\text { frame } 32\end{array}$ & -3.32 & $2.43 \mathrm{E}-10$ & $2.61 \mathrm{E}-12$ \\
\hline MARC_2BOV_I05E23 & e-119 & NM 153425 & TRADD & $\begin{array}{l}\text { TNFRSFIA-associated via death } \\
\text { domain }\end{array}$ & -3.18 & $3.95 \mathrm{E}-07$ & $1.45 \mathrm{E}-08$ \\
\hline C0006007o20 & e-III & NM 001001806 & ZFP36L2 & $\begin{array}{l}\text { Zinc finger protein } 36, \mathrm{C} 3 \mathrm{H} \text { type- } \\
\text { like } 2\end{array}$ & -3.18 & $3.22 \mathrm{E}-09$ & $5.75 \mathrm{E}-\mathrm{II}$ \\
\hline $\mathrm{C} 0005209 \mathrm{~h} 6$ & e- 108 & NM 006163 & NFE2 & $\begin{array}{l}\text { Nuclear factor (erythroid-derived } \\
2 \text { ), } 45 \mathrm{kDa}\end{array}$ & -3.13 & $3.40 \mathrm{E}-06$ & 3.27E-07 \\
\hline C0006019p19 & e-106 & $\underline{X M} 868699$ & TOB2 & Transducer of ERBB2, 2 & -3.13 & 8.37E-07 & $3.31 \mathrm{E}-08$ \\
\hline $\mathrm{C} 0005202 \mathrm{~g} / 3$ & 0.0 & AV594592 & - & EST & -3.11 & $7.3 \mathrm{IE}-04$ & $8.25 \mathrm{E}-05$ \\
\hline C0005208jl & 0.0 & CB221804 & - & EST & -3.10 & $6.65 \mathrm{E}-05$ & $5.18 \mathrm{E}-06$ \\
\hline $\mathrm{C} 0006012 \mathrm{flO}$ & I.00E-67 & NM 145037 & FAM55C & $\begin{array}{l}\text { Family with sequence similarity } 55 \text {, } \\
\text { member } C\end{array}$ & -3.08 & I.03E-II & $6.98 \mathrm{E}-14$ \\
\hline C0005208h20 & 0.0 & CB420023 & - & EST & -3.01 & I.67E-05 & $9.91 \mathrm{E}-07$ \\
\hline
\end{tabular}

Summary of the top 25 genes exhibiting decreased mRNA abundance 2 hours post activation, including clone name, accession number, e-value and identity of the best BLAST match and average fold change. The P and FDRmax values denote the probability from the moderated t-test and the Benjamini and Hochberg false discovery rate values respectively from the analysis of the resting cell values compared to the average activated sample values (Pre v Post).

ual animal values for each gene at 2 hours (data not shown) and 16 hours (Figure 1B) post activation cluster together for 9 of the 10 genes. The CCL2 values have the most spread and one outlying animal influences the difference between the average microarray and qRT-PCR results (Figure 1A). However, the results for IL6 cluster together, illustrating the consistency of the disparity between qRT-PCR and microarray results for this transcript. Investigation of the raw data failed to identify any obvious reason for the lower fold changes measured by microarray analysis, in particular the disparity could not be explained by saturation effects nor excessively low channel intensities (data not shown).

\section{Discussion}

Microarray analysis provides an ideal methodology to investigate the gene expression profile of thousands of genes simultaneously, which allows a broader understanding of complex events, such as m $\phi$ activation and differentiation. Here we describe the construction of a bovine macrophage specific cDNA microarray. The majority of the 5026 clones present on the BoMP microarray have been selected from a normalized bovine $\mathrm{m} \phi$ specific cDNA library [13]. The library was generated from Bos taurus and $B$. indicus derived monocytes and $\mathrm{m} \phi$ subjected to various stimuli, including infection with the protozoan parasite T. annulata, to maximize the number of tran- 
Table 6: The top 25 genes exhibiting increased mRNA abundance 16 hours post activation.

\begin{tabular}{|c|c|c|c|c|c|c|c|}
\hline Clone & E value & Accession No. & Gene Symbol & Gene & Fold Increase & FDRmax & $P$ value \\
\hline pIL8 & 0.0 & NM 173925 & IL8 & Interleukin 8 & 60.09 & $1.23 \mathrm{E}-18$ & 4.9IE-22 \\
\hline MARC_IBOV_94L3 & 0.0 & NM 174300 & CXCL6 & Chemokine (C-X-C motif) ligand 6 & 27.46 & $1.72 \mathrm{E}-\mathrm{I} \mid$ & $1.23 \mathrm{E}-13$ \\
\hline $\mathrm{C} 0006007 \mathrm{~m} 23$ & $2.00 \mathrm{E}-72$ & $\underline{X M 868409}$ & DFNA5 & Deafness, autosomal dominant 5 & 25.42 & $6.52 \mathrm{E}-13$ & $2.72 \mathrm{E}-15$ \\
\hline MARC_3BOV_60PI7 & 0.0 & NM 174299 & $\mathrm{CXCL2}$ & $\begin{array}{l}\text { Chemokine (C-X-C motif) ligand } 2 \\
\text { (GRO } \beta / M I P 2 A)\end{array}$ & 25.14 & $1.25 \mathrm{E}-15$ & $1.24 \mathrm{E}-18$ \\
\hline C0006006kl0 & 0.0 & $\underline{X M 586036}$ & ANKRD37 & Ankyrin repeat domain 37 & 23.35 & 4.05E-07 & I.5IE-08 \\
\hline C00060I6hI5 & 0.0 & $\underline{X M} 613370$ & RGSI & Regulator of G-protein signalling I & 22.10 & 5.10E-09 & $1.00 \mathrm{E}-10$ \\
\hline $\mathrm{C} 0006019 \mathrm{~g} / 2$ & e- 134 & CK965770 & - & EST & 21.24 & $2.26 \mathrm{E}-\mathrm{II}$ & $1.80 \mathrm{E}-13$ \\
\hline $\mathrm{C} 0006019 \mathrm{e} 20$ & 0.0 & $\overline{N M 181015}$ & PRNP & Prion protein & 20.34 & $1.05 \mathrm{E}-20$ & $2.08 \mathrm{E}-24$ \\
\hline $\mathrm{C} 00060 \mid 4 j 10$ & $6.00 \mathrm{E}-96$ & NM 000214 & JAGI & Jagged I & 18.39 & I.8IE-08 & $4.42 \mathrm{E}-10$ \\
\hline C0005208m7 & e-110 & $\underline{N M \quad 000785}$ & CYP27BI & $\begin{array}{l}\text { Cytochrome P450, family } 27 \text {, } \\
\text { subfamily B, polypeptide I }\end{array}$ & 18.39 & 4. $10 \mathrm{E}-09$ & $7.83 \mathrm{E}-\mathrm{II}$ \\
\hline C0006007a22 & 0.0 & NM 022154 & SLC39A8 & $\begin{array}{l}\text { Solute carrier family } 39 \text { (zinc } \\
\text { transporter), member } 8\end{array}$ & 16.01 & $7.46 \mathrm{E}-10$ & I.IOE-II \\
\hline C0005204jl6 & 0.0 & $\underline{X M ~} 864683$ & $\mathrm{CXCL3}$ & $\begin{array}{l}\text { Chemokine (C-X-C motif) ligand } 3 \\
\text { (GRO } \gamma / \mathrm{MIP} 2 \mathrm{~b})\end{array}$ & 15.28 & $1.20 \mathrm{E}-13$ & $3.40 \mathrm{E}-16$ \\
\hline MARC_2BOV_43MI4 & e- 132 & NM 001124 & ADM & Adrenomedullin & 14.23 & $1.20 \mathrm{E}-13$ & $3.00 \mathrm{E}-16$ \\
\hline C0005I98II & e- 138 & B1975933 & - & EST & 11.26 & $2.12 \mathrm{E}-05$ & I.30E-06 \\
\hline MARC_3BOV_I20N2I & e- 102 & NM 172219 & CSF3 & $\begin{array}{l}\text { Colony stimulating factor } 3 \\
\text { (granulocyte) (G-CSF) }\end{array}$ & 11.14 & 8.IIE-II & $7.73 \mathrm{E}-13$ \\
\hline $\mathrm{C} 0006020 \mathrm{e} 20$ & 0.0 & $\underline{C B 419326}$ & - & EST & 10.79 & $9.10 \mathrm{E}-12$ & $5.60 \mathrm{E}-14$ \\
\hline MARC_IBOV_I03H23 & 0.0 & $\underline{X M 586821}$ & IL2RB & Interleukin 2 receptor, beta & 9.96 & $3.73 \mathrm{E}-05$ & $2.52 \mathrm{E}-06$ \\
\hline C0006005pl0 & e-|7| & NM 001102 & ACTNI & Actinin, alpha I & 9.95 & $7.22 \mathrm{E}-08$ & 2.14E-09 \\
\hline $\mathrm{C} 0006020 \mathrm{~m} 09$ & e- $|3|$ & NM 005726 & TSFM & $\begin{array}{l}\text { Ts translation elongation factor, } \\
\text { mitochondrial }\end{array}$ & 9.63 & $5.24 \mathrm{E}-1 \mathrm{I}$ & $4.79 \mathrm{E}-13$ \\
\hline $\mathrm{C} 0006012 \mathrm{n} 18$ & $e-101$ & NM 000362 & TIMP3 & TIMP metallopeptidase inhibitor 3 & 9.50 & 2.7IE-05 & $1.76 \mathrm{E}-06$ \\
\hline $\mathrm{C} 0005202 \mathrm{~d} 9$ & 0.0 & $\underline{X M 870158}$ & ANKRD22 & Ankyrin repeat domain 22 & 9.48 & $6.36 \mathrm{E}-17$ & 3.79E-20 \\
\hline pILIB & 0.0 & NM 000576 & ILIB & Interleukin I, beta & 9.37 & $3.16 \mathrm{E}-13$ & I.07E-15 \\
\hline C0006020dII & 0.0 & $\underline{X M 865242}$ & ZFAND2A & Zinc finger, ANI-type domain $2 \mathrm{~A}$ & 9.28 & I.10E-14 & $1.31 \mathrm{E}-17$ \\
\hline C0005208c5 & e- 100 & NM 002575 & SERPINB2 & $\begin{array}{l}\text { serpin peptidase inhibitor, clade B } \\
\text { (ovalbumin), member } 2\end{array}$ & 9.25 & $3.92 \mathrm{E}-14$ & $6.22 \mathrm{E}-17$ \\
\hline C0005202i8 & 0.0 & $\underline{X M \quad 583725}$ & AРОВECЗА & $\begin{array}{l}\text { Apolipoprotein B mRNA editing } \\
\text { enzyme, catalytic polypeptide-like } 3 \mathrm{~A}\end{array}$ & 8.74 & $1.20 \mathrm{E}-13$ & $2.97 \mathrm{E}-16$ \\
\hline
\end{tabular}

Summary of the top 25 genes exhibiting increased mRNA abundance 16 hours post activation including clone name, accession number, e-value and identity of the best BLAST match and average fold change. The P and FDRmax values denote the probability from the moderated t-test and the Benjamini and Hochberg false discovery rate values respectively from the analysis of the resting cell values compared to the average activated sample values (Pre v Post).

scripts present in the library. A normalized rather than a subtracted library was generated to ensure that non-m $\phi$ specific genes were represented, as we were interested in the complete picture of events during host-m $\phi$ activation and not just the subset unique to $\mathrm{m} \phi$. Furthermore, the majority of murine $\mathrm{m} \phi$ genes exhibiting differential expression after LPS stimulation were not $\mathrm{m} \phi$ specific [10]. Therefore all sequenced clones that matched published sequences were included on the BoMP microarray. The BoMP library also contains a large number of unique sequences and a proportion of these were also included on the microarray. Additionally, a further nearly 450 genes were selected for inclusion on the microarray. Therefore the BoMP microarray is focussed towards investigating the response of myeloid cells, but is of sufficient size and diversity to allow for successful normalization of microarray data.
The BoMP microarray has been validated by investigating the response of bovine monocytes to IFN- $\gamma$ and LPS activation. These compounds are potent, natural activators of myeloid cells and are frequently used, individually or together, to experimentally stimulate monocytes [reviewed in [3]]. A common reference design was used for this microarray experiment. Because only three timepoints, or treatments, were investigated it would have been straightforward to use a loop design, which allows the direct comparison of treatments resulting in higher statistical power than can be obtained from a common reference design [21]. However, the experiment described here forms part of a larger experiment investigating variation in the response of bovine monocytes derived from Holstein-Friesians (B. taurus) and Sahiwal (B. indicus) cattle. Therefore a common reference design was used to allow multifactorial analyses to be carried out looking 
Table 7: The top 25 genes exhibiting decreased mRNA abundance 16 hours post activation.

\begin{tabular}{|c|c|c|c|c|c|c|c|}
\hline Clone & E value & Accession No. & Gene Symbol & Gene & Fold Decrease & FDRmax & $P$ value \\
\hline C00060I7il6 & 0.0 & BM088889 & - & EST & -22.29 & 2.39E-II & $1.94 \mathrm{E}-13$ \\
\hline C000519913 & 0.0 & BT02155I & RNASE4 & Ribonuclease, RNase A family, 4 & -21.08 & I.43E-09 & $2.33 \mathrm{E}-\mathrm{II}$ \\
\hline $\mathrm{C} 0005209 \mathrm{~g} 19$ & - & - & - & Unique singleton & -13.17 & $5.49 \mathrm{E}-13$ & 2.07E- I5 \\
\hline C0005I98n 19 & 0.0 & NM 000014 & A2M & Apha-2-macroglobulin & -12.22 & $6.56 \mathrm{E}-07$ & $2.50 \mathrm{E}-08$ \\
\hline $\mathrm{C} 0006007 \mathrm{~m} 24$ & $1.00 \mathrm{E}-48$ & NM 174594 & RNASE6 & Ribonuclease k6 & -8.88 & $9.11 E-12$ & 5.79E-I4 \\
\hline C0006020f22 & 0.0 & $\underline{X M} 868762$ & CLEC4A & $\begin{array}{l}\text { C-type lectin domain family } 4 \text {, } \\
\text { member A }\end{array}$ & -8.45 & $2.80 \mathrm{E}-06$ & I.27E-07 \\
\hline C0005202116 & $4.00 \mathrm{E}-42$ & $\underline{X M \quad 545369}$ & C6orf32 & $\begin{array}{l}\text { Chromosome } 6 \text { open reading frame } \\
32\end{array}$ & -8.21 & $2.43 \mathrm{E}-10$ & $2.61 \mathrm{E}-12$ \\
\hline BARC_5BOV_46G22 & 0.0 & NM 001037446 & CD59 & CD59 antigen & -8.15 & 2.IIE-07 & 7.20E-09 \\
\hline C0005206dI3 & $4.00 \mathrm{E}-57$ & NM 001009567 & MRCILI & Mannose receptor, C type I-like I & -8.15 & $5.55 \mathrm{E}-10$ & $7.83 \mathrm{E}-12$ \\
\hline C0005I98il8 & I.00E-34 & $\underline{A Y \mid 12657}$ & FGL2 & Fibrinogen-like 2 & -8.04 & 5.69E-07 & 2.16E-08 \\
\hline $\mathrm{C} 0006012 \mathrm{~b} 04$ & 0.0 & DY139256 & - & EST & -6.79 & $8.65 \mathrm{E}-10$ & I.29E-II \\
\hline $\mathrm{C} 0005206 \mathrm{a} 23$ & $e-163$ & CK954547 & - & EST & -6.34 & I.27E-06 & 5.27E-08 \\
\hline $\mathrm{C} 0005920 \mathrm{Cl} 6$ & 0.0 & DN742393 & - & EST & -6.12 & $7.62 \mathrm{E}-08$ & $2.29 \mathrm{E}-09$ \\
\hline MARC_3BOV_43CII & e- $|0|$ & NM 172087 & TNFSFI3 & $\begin{array}{l}\text { Tumor necrosis factor (ligand) } \\
\text { superfamily, member I } 3 \text { (APRIL) }\end{array}$ & -5.81 & I.5IE-08 & 3.57E-10 \\
\hline C000520le6 & e- 100 & NM 005923 & MAP3K5 & $\begin{array}{l}\text { Mitogen-activated protein kinase } \\
\text { kinase kinase } 5\end{array}$ & -5.65 & $5.83 \mathrm{E}-04$ & $6.40 \mathrm{E}-05$ \\
\hline $\mathrm{C} 0006018 \mathrm{f03}$ & $2.00 \mathrm{E}-4 \mathrm{I}$ & DV230110 & - & EST & -5.55 & 3.13E-06 & I.46E-07 \\
\hline $\mathrm{C} 0006005 \mathrm{mlO}$ & $e-|2|$ & NM 001031733 & CALML4 & Calmodulin-like 4 & -5.47 & $2.06 \mathrm{E}-07$ & $6.98 \mathrm{E}-09$ \\
\hline C00052I0kI5 & 0.0 & $\underline{X M} 613642$ & IQGAP2 & $\begin{array}{l}\text { IQ motif containing GTPase } \\
\text { activating protein } 2\end{array}$ & -5.45 & I.58E-07 & $5.13 \mathrm{E}-09$ \\
\hline C0005199n6 & 0.0 & NM 001033990 & $\mathrm{SCP} 2$ & Sterol carrier protein 2 & -5.44 & $3.32 \mathrm{E}-09$ & 5.99E-II \\
\hline C0005209n7 & $7.00 \mathrm{E}-95$ & NM 001386 & DPYSL2 & Dihydropyrimidinase-like 2 & -5.16 & $8.42 \mathrm{E}-08$ & $2.58 \mathrm{E}-09$ \\
\hline MARC_2BOV_I4NI3 & $e-|5|$ & $\underline{X M \quad 582744}$ & ILI6 & Interleukin 16 & -5.12 & $9.35 \mathrm{E}-10$ & I.4IE-II \\
\hline $\mathrm{C} 0006016 \mathrm{k} 03$ & e- 124 & XM 607564 & FLII & Friend leukemia virus integration I & -4.88 & $1.90 \mathrm{E}-05$ & I.14E-06 \\
\hline $\mathrm{C} 0005209 \mathrm{~m} 4$ & 0.0 & $\underline{X M \quad 583952}$ & IL6R & Interleukin 6 receptor & -4.88 & $2.49 \mathrm{E}-\mathrm{II}$ & $2.08 \mathrm{E}-13$ \\
\hline MARC_2BOV_42H5 & 0.0 & NM 001014945 & CIQA & $\begin{array}{l}\text { Complement component I, q } \\
\text { subcomponent, alpha }\end{array}$ & -4.86 & 8. $14 \mathrm{E}-06$ & $4.32 \mathrm{E}-07$ \\
\hline $\mathrm{C} 00060 \mathrm{I} 8 \mathrm{i} 05$ & 0.0 & $\underline{X M ~ 615814}$ & FKBP5 & FK506 binding protein 5 & -4.65 & 7.14E-09 & $1.46 \mathrm{E}-10$ \\
\hline
\end{tabular}

Summary of the top 25 genes exhibiting decreased mRNA abundance 16 hours post activation, including clone name, accession number, e-value and identity of the best BLAST match and average fold change. The P and FDRmax values denote the probability from the moderated t-test and the Benjamini and Hochberg false discovery rate values respectively from the analysis of the resting cell values compared to the average activated sample values (Pre v Post).

across the time course and between cattle breeds. In addition, the same common reference sample has been used in a separate microarray experiment investigating the response of bovine monocytes to $T$. annulata infection (Jensen et al., in prep).

There are an increasing number of microarrays available to investigate bovine gene expression [reviewed by [3]]. A sub-set of these have been designed to specifically investigate the immune response. The majority of publications have made use of versions of the bovine total leukocyte (BoTL) microarray [22]. The latest version, BoTL-5 contains 1391 genes and controls [23]. Other arrays include the bovine immune-endocrine cDNA microarray containing amplicons representing 167 genes [24]. Recently a bovine innate immunity microarray has been described which contains over 6800 clones [25]. The majority of these clones have been selected from normalized and subtracted libraries and have not been sequenced. Therefore there is likely to be considerable redundancy on this microarray and its full scope is not known.

However, microarray studies investigating the response of bovine monocytes and $m \phi$ to infection and activation have not made use of these focussed microarrays. The response of monocytes to Escherichia coli 0157:H7 LPS was investigated using Incyte Genomics UniGEM V 1.0 human cDNA microarray [4]. Cells were activated for 3 hours and bovine monocyte RNA hybridized with approximately $80 \%$ of the gene targets. A total of 44 differentially expressed genes were identified, 21 of which are represented on the BoMP microarray. However, only 13 of these genes exhibited differential expression in the study reported here, including pentraxin-related gene, rapidly induced by IL1 $\beta$ (PTX3), CASP8 and FADD-like apoptosis regulator (CFLAR) and TIMP3. The remaining 8 genes identified in the earlier study as being differentially expressed during activation are not exhibiting differential 
Table 8: Details of the qRT-PCR primers and amplicons.

\begin{tabular}{|c|c|c|c|c|c|}
\hline Gene & Gene Symbol & Clone & Direction & Sequence $\left(5^{\prime}-3^{\prime}\right)$ & Size (bp) \\
\hline \multirow[t]{2}{*}{ CD9 antigen } & CD9 & BE75I736 & $\mathrm{F}$ & TTG GAC TAT GGC TCC GAT TC & 261 \\
\hline & & & $\mathrm{R}$ & ССТ TGA TCA ССТ ССТ ССТ TG & \\
\hline \multirow{2}{*}{ CD44 antigen } & CD44 & AJ816969 & $\mathrm{F}$ & TAC CCA CCC ACA AGA GAA CC & 102 \\
\hline & & & $\mathrm{R}$ & AAC CCA TTA CCA GTC ATC CTT G & \\
\hline \multirow[t]{2}{*}{ CD86 antigen } & CD86 & pCD86 & $\mathrm{F}$ & GAA GGT CCC AAG GAT TGG TT & 136 \\
\hline & & & R & GAT GAG CAG GTC AAA TTG ATG A & \\
\hline \multirow[t]{2}{*}{ Chemokine ( $\mathrm{C}-\mathrm{C}$ motif) ligand 2} & CCL2 & AJ821161 & $\mathrm{F}$ & TCG CCT GCT GCT ATA CAT TC & 274 \\
\hline & & & $\mathrm{R}$ & AGA GGG CAG TTA GGG AAA GC & \\
\hline \multirow{2}{*}{ Chemokine (C-C motif) receptor I } & CCRI & BE756795 & $\mathrm{F}$ & AAA TGA GAA GAA GGC CAA AGC & 140 \\
\hline & & & $\mathrm{R}$ & TGC TCT GCT CAC ACT TAC GG & \\
\hline \multirow[t]{2}{*}{ Complement component I, $r$ subcomponent } & CIR & AJ818500 & $\mathrm{F}$ & AGA TTT GTC CGT CTG CCA GT & 183 \\
\hline & & & $\mathrm{R}$ & CCC AGC GGT CAT TTC TCT TA & \\
\hline \multirow[t]{2}{*}{ Fibronectin I } & $\mathrm{FNI}$ & AJ819936 & $\mathrm{F}$ & TAT CTT GGT GCC ATT TGC TC & 258 \\
\hline & & & $\mathrm{R}$ & ATC CAC GCT TGT TTC TCT GG & \\
\hline \multirow[t]{2}{*}{ Interleukin 6} & IL6 & pIL6 & $\mathrm{F}$ & TGA GTG TGA AAG CAG CAA GG & 289 \\
\hline & & & $\mathrm{R}$ & CAG CAG GTC AGT GTT TGT GG & \\
\hline \multirow[t]{2}{*}{ Prion protein } & PRNP & AJ821011 & $\mathrm{F}$ & TGT GTA TGG TGG GAT TGG AA & 197 \\
\hline & & & $\mathrm{R}$ & GCT GGG TCA TCA AAG AAA TG & \\
\hline \multirow[t]{2}{*}{$V$-fos FBJ murine osteosarcoma viral oncogene } & FOS & BE755II7 & $\mathrm{F}$ & СTT CTC CAG CAT GGG TTC TC & 257 \\
\hline & & & $\mathrm{R}$ & TCT GAG CTC TGC CTC CTG TC & \\
\hline \multirow[t]{2}{*}{ Chromosome 13 open reading frame 8} & CI3orf8 & AJ817183 & $\mathrm{F}$ & AGC AGT GAC CAA GAG CAG GT & 205 \\
\hline & & & $\mathrm{R}$ & TCA TAG CAC GAC AGC AAC AA & \\
\hline
\end{tabular}

$\mathrm{F}$ and $\mathrm{R}$ denote forward and reverse primers respectively.

expression during the time course reported here, e.g. CASP4 and tumour necrosis factor (TNF- $\alpha$ ). These results could indicate a genuine difference in the response to the two different stimuli, be due to other technical differences between the two studies or be due to the failure of the DNA from the representative clone to hybridize correctly. The latter is true for TNF- $\alpha$, the expression of which we have previously shown to differ during monocyte activation (data not shown). The failure of this clone has prompted us to include additional clones representing TNF- $\alpha$ on the next version of the microarray, which is currently under construction.

There is a considerable difference in the number of differentially expressed genes identified in LPS stimulated cells (44 genes) compared to the study reported here (695 genes). The earlier study compared gene expression in LPS stimulated cells with cells cultured in medium only and therefore the response of the cells to LPS alone was investigated [4]. In contrast, the study reported here has investigated the response of cells to LPS and IFN- $\gamma$ compared to resting cells and therefore the cells are also responding to being in culture conditions for the first time. Furthermore, our cells were stimulated immediately after isolation, whilst the previous study used cells that were cultured overnight before treatment [4].

Bovine derived microarrays have been used to investigate gene expression in bovine monocytes and $\mathrm{m} \phi$ in two studies [[6] \&[8]]. The response to alveolar $\mathrm{m} \phi$ to infection with virulent and attenuated strains of Mycobacterium bovis has been investigated using an in house cDNA microarray [8]. In addition, a commercially available bovine microarray produced by Pyxis Genomics [26] was used to compare gene expression of bovine monocyte-derived $\mathrm{m} \phi$ (MDM) infected with M. avium subspecies paratuberculosis and $M$. a. avium [6]. This cDNA microarray was constructed from bovine spleen and placental cDNA libraries; however, immunologically important genes are poorly represented on the microarray. For example, the principal proinflammatory cytokines, IL1 $\beta$, IL6 and TNF- $\alpha$, are not represented. Therefore the microarray is of limited use when investigating aspects of the immune system.

Microarray analysis has been used to investigate the response of human and murine derived $m \phi$ to LPS and IFN- $\gamma$ [reviewed in [3]]. A total of 219 genes exhibited differential expression 6 hours post LPS treatment in the murine cell line RAW264.7 [27]. Of these 85 (38.8\%) are represented on the BoMP microarray and $42.4 \%$ (36) of these exhibit similar fold changes. The $\mathrm{m} \phi$ response to a range of pathogens and PAMPs has been investigated simultaneously $[28,29]$. A shared activation program of expression changes in 191 human m $\phi$ genes was found in response to a range of bacterial pathogens, the majority of which were also activated by LPS [28]. Ninety-four of these genes are represented on the BoMP microarray and $64 \%$ of up-regulated genes in the activation program were also up-regulated in the current study, e.g. ninjurin 1 (NINJ1), prostaglandin-endoperoxide synthase 2 

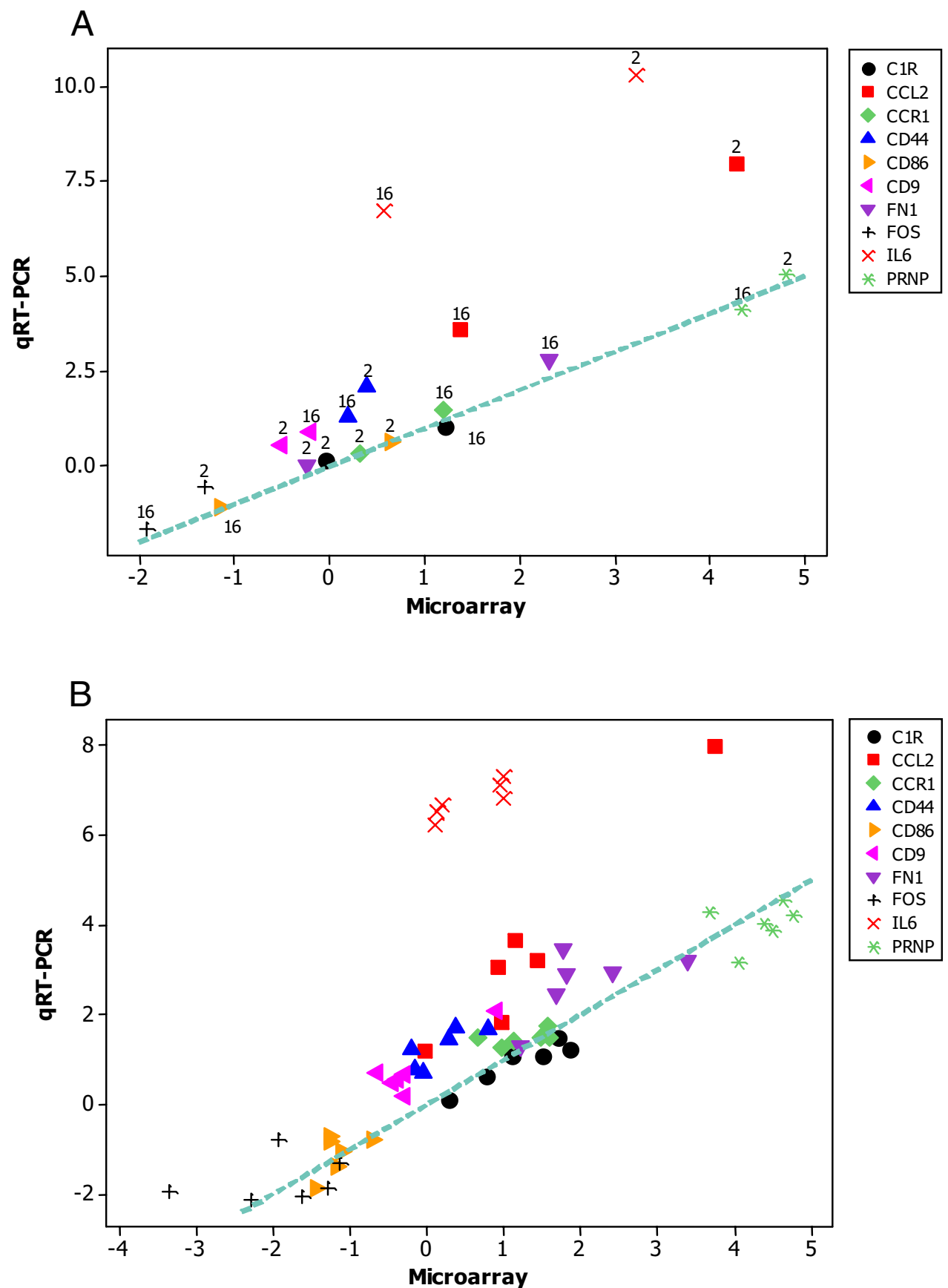

Figure I

Scatterplots comparing the differential expression measured by qRT-PCR and microarray analysis for 10 investigated genes at 2 time points after activation. A, average log(differential expression). The numbers indicate the time post activation. B, log(differential expression) of individual animals at 16 hours post activation. The 10 investigated genes were CIR (black circle), CCL2 (red square), CCRI (green diamond), CD44 (blue triangle), CD86 (orange triangle), CD9 (pink triangle), FNI (purple triangle), FOS (black cross), IL6 (red cross) and PRNP (green star). The dotted lines denote the lines of equality $(y=x)$. 
(PTGS2), nuclear factor of kappa light polypeptide gene enhancer in B-cells inhibitor, alpha (NFKBIA) and jagged 1 (JAG1).

The expression of 10 genes was investigated by qRT-PCR to validate the microarray results. The same RNA samples were used for this analysis, rather than the collection of additional samples, because the principal aim was to confirm to results obtained from the microarray experiment rather than to investigate the expression of particular genes. Overall there was good correlation between the microarray and qRT-PCR results, with a correlation value of 0.78. This level of correlation is comparable to that seen in a large scale validation study of over 1300 genes recently reported [30]. However, the dominant pattern observed in the comparison of microarray and qRT-PCR results reported here closely follows the line of equality, which was not observed in the large scale study [30]. The average logarithms of differential expression for the two time points were remarkably similar for 6 of the 10 genes. The qRT-PCR analysis was more sensitive for the remaining 4 genes and detected increased differential expression over the microarray analysis, particularly for IL6, which was underestimated by as much as 100 fold. There are several possible explanations for the disparity between these methodologies, including; fluorescence saturation and specificity. However, analysis has confirmed that the disparity in IL6 results is not caused by the saturation of the fluorescence on the microarray (data not shown). Closely related gene-family members, sharing more than $80 \%$ sequence homology, can cross-hybridize in cDNA microarray experiments resulting in false positive results [31]. However, this can not explain the results for IL6, which is not part of a closely related gene family and the hybridization signals were lower than expected. The most probable cause of the disparity in IL6 results is sub-optimal hybridization of IL6 on the microarray. In contrast, the qRT-PCR amplification is optimized on a gene basis.

Due to the limited amount of totRNA generated from the peripheral monocytes, the microarray experiment was carried out using aRNA. The suitability of this approach has been validated by previous studies [32]. The qRT-PCR was carried out on the original totRNA samples used to generate the aRNA used in the microarray experiment. The similarity between the majority of the results supports the use of aRNA for microarray analysis. However, variable amplification of transcripts may account for the disparity between the qRT-PCR and microarray results for IL6. This could be investigated by repeating the qRT-PCR analysis using the aRNA samples. Unfortunately, this was not possible due to limited amounts of the samples remaining. The $\log$ (fold changes) were encouragingly consistent between animals for all but one of the genes examined. A comparison of the results of statistical significance tests for the two methodologies has not been attempted. The microarray results would require recalculating for a fair comparison, as they are penalized for the multiple testing of over 5000 genes and also have the residual variances for each gene "shrunk" towards the median residual variance to improve the false discovery rate for the list of top genes exhibiting differential expression.

Further investigation of the validity of the microarray results concentrated on the top gene lists (Tables 4, 5, 6, 7 ), by in silico analysis, searching the literature for corroborative data. Unfortunately, corroborative data has not been found for a proportion of the genes. Several of the most differentially expressed genes currently only match ESTs or are unique to the BoMP library. Exploration of these may provide insights into novel pathways involved in the reprogramming of the innate immune cell after infection or inflammation. Further work on the bovine genome sequencing project should provide more information on these sequences in the future.

Results for two of the top differentially expressed genes are inconsistent with previously published data. Dihydropyrimidinase-like 2 (DPYSL2) is down-regulated over 5 fold in this study. However, expression of the gene has been reported as up-regulated upon monocyte activation [33]. Similarly, previous studies have shown that C1Q is upregulated during LPS and IFN- $\gamma$ stimulation [34]. In the current study both C1QA and C1QB are down-regulated 4.8 fold and 2.9 fold respectively. The disparity between the results may result from differences in experimental design, cell types or species differences, or from other technical differences between the studies.

Many of the top differentially expressed genes have been shown to be differentially expressed in activated myeloid cells by previously microarray analysis. Sixteen of the genes were listed in the $\mathrm{m} \phi$ activation program, including; $\mathrm{N}$-sulfoglucosamine sulfohydrolase, adrenomedullin and ribonuclease k6 [28]. Similarly seven of the top genes were also described in the study of gene expression in RAW264.7 cells, e.g. exportin 1 [27] and three of the top genes were differentially expressed in the only other published paper on bovine monocyte gene expression, e.g. TNF- $\alpha$ induced protein 3 (TNFAIP3) [4].

The biological function of prion protein is still unclear, although mRNA and protein levels increase upon activation of many leukocytes, including T lymphocytes [35]. $\mathrm{M} \phi$ from prion protein knockout mice show lower rates of phagocytosis and recruit a different subset of leukocytes, suggesting that the protein plays an important role in $\mathrm{m} \phi$ function [36]. Differentiation of monocytes to dendritic cells (DC) increases surface expression of prion protein 
[37] and IFN- $\gamma$ stimulation triggers increased prion protein expression in CD14+ peripheral cells [35].

Exposure to IFN- $\gamma$ also induces phorbol-12-myristate-13acetate-induced protein 1 (PMAIP1) expression, which disrupts the mitochondrial outer membrane integrity and is involved in apoptosis [38]. Apolipoprotein B mRNA editing enzyme, catalytic polypeptide-like 3A (APOBEC3A) acts to inhibit retroviral replication and expression of the closely related proteins APOBEC3B and APOBEC3C are stimulated by IFN- $\gamma$ [39].

An additional 13 genes from the top differentially expressed genes have been shown to be differentially expressed in myeloid cells after LPS treatment. These include up-regulation of IL2RB [40] and down-regulation of IL6R [41], CCR2 [42] and CD59 [43]. Similarly, the nuclear receptor subfamily 4 , group $\mathrm{A}$, member 3 (NR4A3), which is mediated by NF-KB signalling is upregulated in RAW264.7 stimulated with LPS [44]. Furthermore, the zinc transporter solute carrier family 39 member 8 (SLC39A8) is expressed at very low levels in unstimulated monocytes, but levels increase after LPS stimulation [45].

The information described in this report, particularly the expression changes in unique or unknown genes, may in the future suggest new candidates for disease resistance genes. Furthermore, the results may suggest new ways to effectively stimulate the innate immune system, leading to improvements in the design of vaccines and adjuvants.

\section{Conclusion}

Here we report the construction of a $5 \mathrm{~K}$ bovine macrophage specific cDNA microarray, which has been validated by investigating the response of bovine monocytes to culturing and stimulation with IFN- $\gamma$ and LPS. Over 690 differentially expressed genes were identified and the results for a selection of these genes have been confirmed by qRT-PCR analysis. Therefore the BoMP microarray is a useful resource for investigating gene expression in bovine myeloid cells. A second version of the microarray is currently under construction, which contains an additional 500 clones to improve the representation of various biological pathways on the microarray. Both versions of the BoMP microarray will be publicly available through the ARK-Genomics Centre for Functional Genomics in Farm Animals [18].

\section{Methods \\ Construction of the BoMP microarray Clone selection}

5026 sequence elements have been chosen for inclusion on the BoMP microarray, see Additional file 1 for a complete annotated list. These have been derived from a number of resources (Table 1). The majority of the clones (4585 clones) were derived from the normalized BoMP cDNA library [13], generated from RNA samples collected from $B$. taurus and B. indicus derived cells subjected to various stimuli. A further 381 clones were selected from the MARC 1-4 BOV libraries and others available at the ARKGenomics facility [16,17]. In addition, 60 amplicons were generated to represent immunologically important genes that were not available in the libraries at our disposal, e.g. IL6 and IL8.

\section{Generation of amplicons}

Sixty immunologically important genes were selected for amplicon generation (Table 2). Oligonucleotides were designed for the 60 genes using the Primer3 website $[46,47]$. First strand cDNA was reverse transcribed from $0.5 \mu$ m meloid cell totRNA using oligo(dT) primer and Superscript II (Invitrogen) according to the manufacturer's instructions. Two microlitres of the cDNA was amplified using the gene specific primers in a $100 \mu \mathrm{l}$ polymerase chain reaction (PCR) containing the following; $1 \times$ PCR buffer, $1.5 \mathrm{mM} \mathrm{MgCl} 2,200 \mu \mathrm{M}$ dNTP mix, $200 \mathrm{nM}$ forward and reverse primers and 0.5 units Taq polymerase (ABgene). PCR amplification was carried out using the following cycle profile: one cycle of $95^{\circ} \mathrm{C}$ for 3 minutes, $60^{\circ} \mathrm{C}$ for 30 seconds and $72^{\circ} \mathrm{C}$ for 45 seconds, followed by 39 cycles of $95^{\circ} \mathrm{C}$ for 30 seconds, $60^{\circ} \mathrm{C}$ for 30 seconds and $72^{\circ} \mathrm{C}$ for 45 seconds. The final cycle had an extension at $72^{\circ} \mathrm{C}$ for 5 minutes. The PCR products were purified using QIAquick Gel Extraction Kit (Qiagen) before being cloned into pGEM-T easy vector (Promega) according to the manufacturer's instructions. The resulting plasmids were sequenced to ensure amplification of the specific product (data not shown).

\section{Microarray construction}

The BoMP microarray was constructed from the 5026 clones described above and additional controls, including; chicken and bovine genomic DNA, calf thymus DNA, salmon sperm DNA, glyceraldehyde-3-phosphate dehydrogenase (GAPDH), $\gamma$-actin, landing lights, spotting buffer and the Alien SpotReports 1-10 (Stratagene). The controls are distributed evenly across the microarray. The plasmid DNA was purified using MagAttract 96 Miniprep chemistry on a Biorobot 8000 platform (Qiagen). The cDNA inserts were PCR amplified using the oligonucleotides CGATTAAGTTGGGTAACGC and CAATTTCACACAGGAAACAG in $50 \mu \mathrm{l}$ reactions using $1 \mu \mathrm{l}$ plasmid template. Amplified DNA was purified by Multiscreen 384 well PCR purification plates (Millipore) on a Multiprobe II liquid handling platform (Perkin Elmer). The presence of products was confirmed by agarose gel electrophoresis and quantified by Picogreen assay (Molecular Probes) on a Flouroskan Ascent flourescent plate reader (Thermo Life Science). 
DNA was resuspended to $150 \mathrm{ng} / \mu \mathrm{l}$ in spot buffer (150 $\mathrm{mM}$ sodium phosphate, $0.01 \%$ sodium dodecyl sulphate) before being spotted in duplicate on to amino-silane coated GAPSII slides (Corning) using a Biorobotics MicroGrid II spotter (Genomic Solutions). The microarray is laid out in a $12 \times 4$ grid, where each block corresponds to one of 48 print tips. Each block comprises a $16 \times 15$ grid of spots.

Printed microarray slides were treated using succinic anhydride and 1-methyl-2-pyrrolidinone (Sigma) to block unbound amino groups, followed by a wash in $95^{\circ} \mathrm{C}$ MilliQ water before hybridization.

\section{Sample collection}

Peripheral blood was isolated from 6 Holstein-Friesian (B. taurus) cattle maintained at the Roslin Institute, UK. These animals, 2 females and 4 males, were between 1-3 years of age and kept on pasture. The blood was collected aseptically into acid citrate dextrose and immediately stored on ice. Under cold conditions peripheral blood mononuclear cells (PBMC) were separated by density gradient centrifugation on Lymphoprep (Axis-Shield), washed three times with phosphate buffered saline (PBS) and resuspended at $10^{7}$ cells $/ \mathrm{ml}$ in PBS supplemented with $1 \%$ foetal bovine serum (FBS). Peripheral monocytes were isolated from PBMC by positive selection using a predetermined optimum concentration of the monoclonal antibody IL-A24, which recognizes signal-regulatory protein alpha (SIRPA) [48], and the MACS system according to the manufacturer's instructions (Miltenyi Biotec). FACS analysis confirmed that the cell purity exceeded 95\% (data not shown).

The purified monocytes from each animal were resuspended at $10^{7} \mathrm{cells} / \mathrm{ml}$ in RPMI-1640 medium supplemented with $10 \%$ FBS, $20 \mathrm{ng} / \mathrm{ml}$ LPS derived from E. coli serotype 055:B5 (Sigma) and $300 \mathrm{U} / \mathrm{ml}$ recombinant ovine IFN- $\gamma$, kindly supplied by Dr. G. Entrican (Moredun Research Institute). Cells from each animal were divided into 3 aliquots and incubated at $37^{\circ} \mathrm{C}$ in a $5 \% \mathrm{CO}_{2}$ incubator. The cells were harvested at 0,2 , and 16 hours post activation. The activated monocytes were pelleted, washed with PBS and stored in RNAlater (Ambion) at $4{ }^{\circ} \mathrm{C}$ before RNA extraction.

\section{RNA preparation}

totRNA was extracted from the 18 cell samples using the RNeasy mini kit (Qiagen) according to the manufacturer's instructions. The quality and quantity of the resulting RNA was determined by gel electrophoresis, spectrophotometry at $260 \mathrm{~nm}$ and $280 \mathrm{~nm}$ and by Agilent 2100 Bioanalyzer. Linearly amplified aRNA was generated from 0.5 $\mu \mathrm{g}$ totRNA using the MessageAmp aRNA kit (Ambion) according to the manufacturer's instructions and incorpo- rating modified 5-(3-aminoallyl)-UTP. All totRNA samples underwent a single round of amplification. The quality and the quantity of the resulting aRNA was analysed by spectrophotometry and Agilent 2100 Bioanalyzer.

\section{RNA labelling \& hybridizations}

Fluorescent cyanine (Cy) dyes, either Cy3 or Cy5 as appropriate, were indirectly incorporated into each $1.2 \mu \mathrm{g}$ aRNA sample by coupling to the modified UTP using the protocol described on the ARK-Genomics website [18]. The labelled aRNA was purified using a DyeEx spin column (Qiagen) and the labelling efficiency was determined by running $0.5 \mu \mathrm{l}$ of each sample on a $1 \%$ agarose gel.

Hybridizations were carried out in a GeneTac automated hybridization station (Genomic Solutions). The Cy3 and Cy5 labelled aRNA were mixed and added to $125 \mu \mathrm{l}$ hybridization solution (ARK-Genomics protocols [18]) and hybridized onto the BoMP microarray for 12 hours. The microarray slides were then washed in wash buffers of increasing stringency (Genomic Solutions). After removal from the hybridization station the microarray slides were sequentially washed in post wash buffer and isopropanol for one minute before being dried by centrifugation at 220 $\mathrm{g}$ for 6 minutes. The dried slides were scanned in a Scanarray $5000 \mathrm{XL}$ scanner (GSI Lumonics) at constant laser power of $80 \%$ and $78 \%$ for $\mathrm{Cy} 3$ and Cy5 respectively.

\section{Experimental design}

The experiment described here was part of a larger microarray experiment of 36 microarray slides comparing the response of monocytes derived from 6 Holstein-Friesian (B. taurus) and 5 Sahiwal (B. indicus) cattle to stimulation with IFN- $\gamma$ and LPS, which will be described elsewhere (Jensen et al., in prep). The RNA samples from each animal and time point were analyzed separately. The resulting aRNA from each sample was hybridized in competition with a pooled reference sample, made up of 5 resting monocyte aRNA samples; 3 Sahiwal and 2 Holstein samples. A common reference design was used to simplify the multifactorial analysis of the complete experiment. The reference sample was labelled with $\mathrm{Cy} 3$ and the treatment sample with Cy5 on each microarray slide. The microarray data has been submitted to ArrayExpress and assigned the accession number E-MAXD-16 [19,20].

\section{Microarray data analysis}

Microarray spot intensity and quality data were extracted from the scanned images using the BlueFuse software version II (BlueGnome). Each slide was normalized separately, using the $\log _{2}$-ratios of treatment to reference intensities for all the non-control spots. Normalization and analysis was based on the Limma package of Biocon- 
ductor [49], with additional plotting from the Bioconductor Marray package. However, the Limma models were modified at both the normalization and analysis stages. The normalization was a 2-step process of spatial then intensity dependent bias correction. The spatial bias correction was carried out separately for each $2 \times 2$ group of blocks, by subtracting corresponding row and column means (RC correction, excluding control spots) from each data spot. This simple correction has been used in crop experiments to remove spatial trends and has also been suggested for similar trends across microarrays [50]. The rows and columns may stretch across the whole slide (global) or only across the spots within a block, to more strongly reflect local spatial patterns. The choice of $2 \times 2$ groups of blocks results in a smoothing of the spatial pattern intermediate between these two. The intensity dependent bias was removed by local block-lowess [51]. The choice of level, global or local, for the two normalization steps was informed by examination of spatial heat diagrams and M-A plots for all possible normalization combinations (Figure 2).

The time course effects of the log ratios of treatment to reference for means of replicate spots on each microarray slide were analyzed by regression models, which allowed for repeated observations from each animal. The Limma eBayes correction [52] was used to shrink the residual variances of genes towards their approximate median value. The effect of time was assessed by two comparisons; firstly, the values from resting samples were compared to activated sample values (at both 2 or 16 hours). Secondly, the 2 hour values were compared to the 16 hour values. Comparisons were made using Smyth's moderated t-test [52]. FDRmax values for each contrast were calculated using the method of Benjamini and Hochberg [53], the default multiple testing method in Limma. Genes with FDRmax values less than or equal to 0.01 were considered as significantly different. To refine the list of differentially expressed genes further to those of probable biological relevance, only those genes exhibiting a 2 fold or greater average change at 2 hours or 16 hours post activation compared to resting cells were considered.

\section{Validation of microarray results}

Quantitative RT-PCR was carried out on 10 genes to verify the microarray results. Oligonucleotides were designed for each gene using Primer3 $[46,47]$ and Netprimer (Biosoft International) software [54] (Table 8). The qRT-PCR analysis was carried out on the same totRNA samples from Holstein-derived monocytes used to generate aRNA for the microarray experiment. First strand cDNA was reverse transcribed from $0.5 \mu \mathrm{g}$ totRNA using oligo(dT) primer and Superscript II (Invitrogen) according to the manufacturer's instructions. The resulting cDNA was diluted 1:50 for all genes except FOS, when the cDNA was diluted 1:10. FOS was down-regulated during activation and therefore a more concentrated cDNA sample was required for successful qRT-PCR amplification of FOS in the 16 hour time points.

The mRNA levels of each transcript were quantified by PCR using the Platinum SYBR Green qPCR Supermix UDG kit (Invitrogen). Reactions were carried out in $20 \mu \mathrm{l}$ volumes containing; $1 \times$ supermix (Sybr Green, Platinum taq DNA polymerase, dNTPs, UDG and stabilizers), $0.4 \mu \mathrm{l}$ Rox dye, $1 \mu \mathrm{l}$ forward and reverse primers at predetermined optimal concentrations and $5 \mu$ l diluted cDNA. Amplification and detection of products was carried out using a Mx3000P PCR machine (Stratagene) with the following cycle profile: $50^{\circ} \mathrm{C}$ for 2 minutes, $95^{\circ} \mathrm{C}$ for 2 minutes followed by 40 cycles of $95^{\circ} \mathrm{C}$ for 15 seconds and $60^{\circ} \mathrm{C}$ for 30 seconds. The detection of a single product was verified by dissociation curve analysis. Each PCR experiment was carried out in triplicate and contained several non-template controls and $a \log _{10}$ dilution series of the representative clone from the array or activated monocyte RNA. The relative quantities of mRNA were calculated using the method described by Pfaffl [55]. The qRT-PCR results for Chromosome 13 open reading frame 8 (C13orf8) [EMBL: AJ817183] were used to calculate differences in the template RNA levels and thereby standardize the results for the genes of interest. C13orf8 was selected from microarray and qRT-PCR analyses as a constitutively and moderately expressed gene in activated, $T$. annulata-infected and resting Holstein and Sahiwal derived monocytes (data not shown). Where Pfaffl [55] uses ratios of the control gene to target gene values, we use the differences between the corresponding logarithms of these values. The qRT-PCR values are then comparable with the $\log$ (intensity ratios) from the microarray analysis, both in scale and as estimates of the $\log$ (geometric mean) values.

\section{Authors' contributions}

$\mathrm{KJ}$ designed the microarray, collected the RNA samples and drafted the manuscript. RT constructed the microarray and carried out the microarray experiments. DW statistically analyzed the microarray data. EP and KJ carried out the qRT-PCR analysis. EJG was involved in the microarray and experimental design. All authors read and approved the final manuscript. 


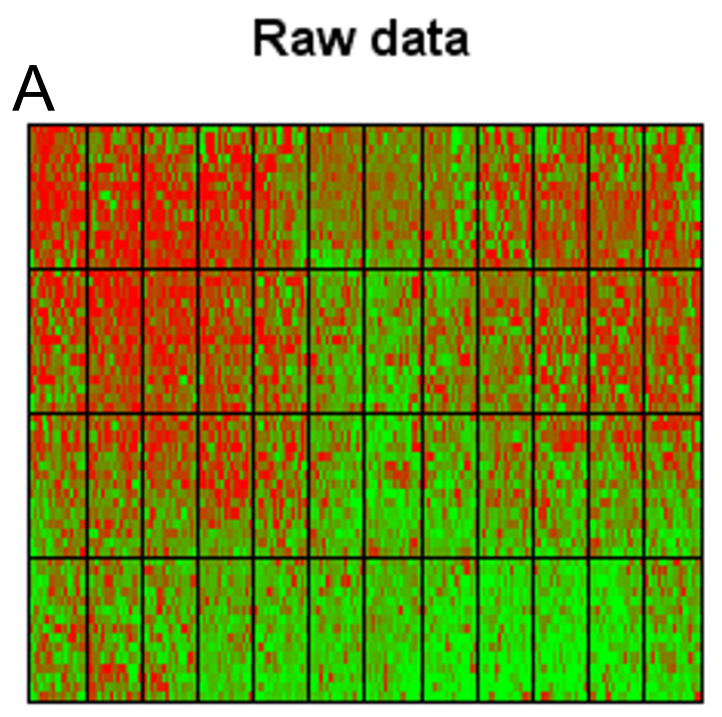

2-range -7.9 to 4.1 (saturation -0.8, 2.1)

\section{Normalised data}

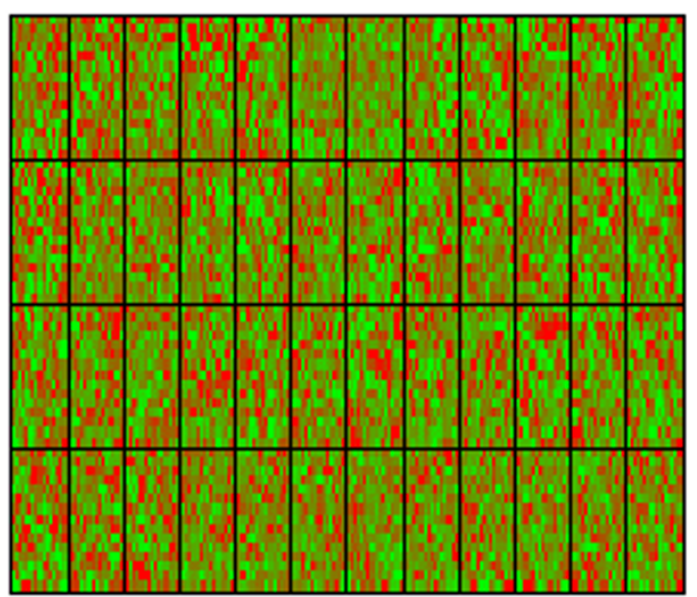

2-range -8.9 to 3.8 (saturation $-0.9,1.2$ )

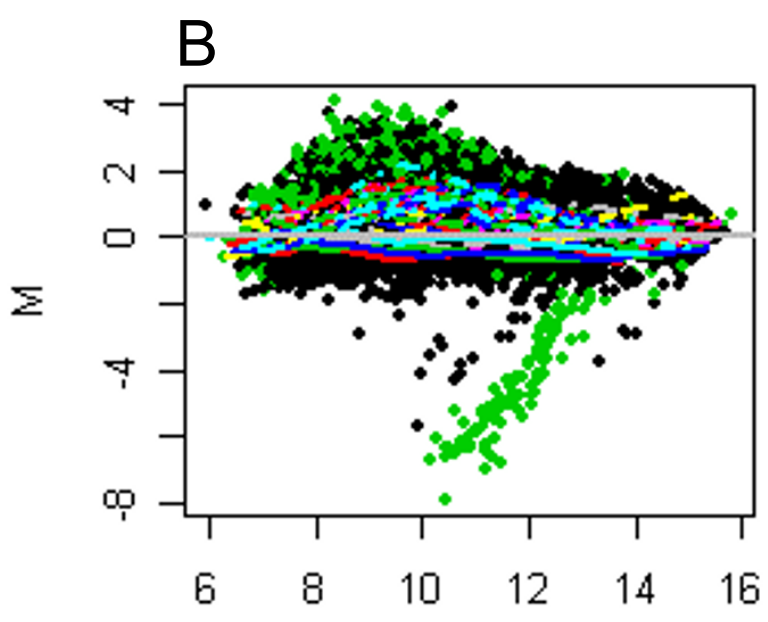

A

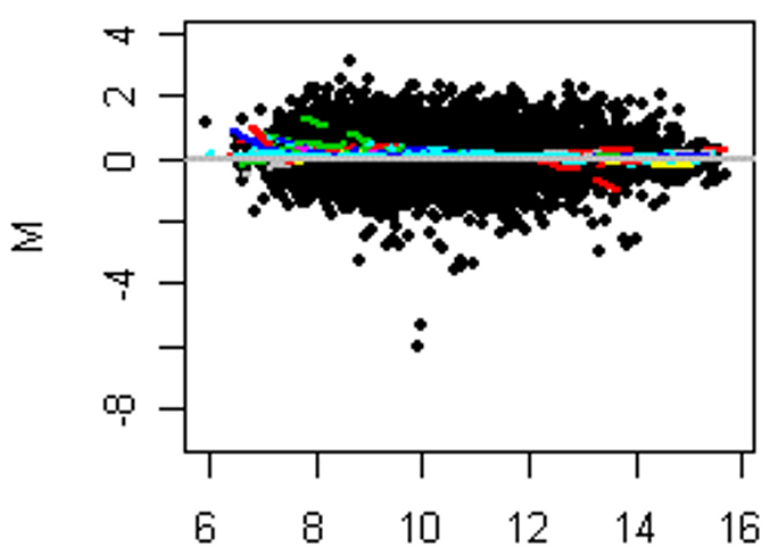

A

\section{Figure 2}

Representative spatial heat maps and M-A plots of raw and normalized data. A, spatial heat map for a representative microarray slide before and after normalization. The footnote gives the range of $M$ values for the slide ( $z$-range) and the range excluding the extreme $5 \%$ tails of the distribution of $M$ values (saturation) which are excluded from the plot. B, M-A plots for the same representative microarray slide before and after normalization. Green spots denote control genes and the coloured lines represent the curve for each print tip. 


\section{Additional material}

\section{Additional File 1}

Annotation of the BoMP microarray. An excel file of the annotation of the BoMP microarray is available as supplementary material and is also found on the Roslin Institute website [56]. Where possible the best human RefSeq hit has been listed for analysis purposes. Clones highlighted in blue denote those containing non-bovine sequences.

Click here for file

[http://www.biomedcentral.com/content/supplementary/14712164-7-224-S1.xls]

\section{Additional File 2}

List of clones exhibiting statistically significant differential expression during monocyte activation with IFN- $\gamma$ and LPS. An excel file listing the 695 genes exhibiting differential expression during monocyte activation ( $\geq 2$ fold, $P<0.01$, FDRmax $<0.01$ ). Fold increases and decreases are highlighted in orange and green respectively. Genes shown in bold are represented by more than one clone. The calculated $P$ values and FDRmax values are included for the 2 analyses of the affect of time; Pre $v$ Post, resting sample compared to activated samples; $2 \mathrm{hr} v 16 \mathrm{hr}, 2$ hour values compared to 16 hour values.

Click here for file

[http://www.biomedcentral.com/content/supplementary/14712164-7-224-S2.xls]

\section{Acknowledgements}

We thank Gary Entrican (Moredun Research Institute, UK) for kindly supplying the recombinant ovine IFN- $\gamma$. We also thank Mark Fell (Roslin Institute) for his help submitting the microarray and experimental data to ArrayExpress. This work was undertaken with financial support from the BBSRC (2I5/SI5354) and Dave Waddington is funded by the Veterinary Training Research Initiative.

\section{References}

I. Glass EJ, Innes EA, Spooner RL, Brown CG: Infection of bovine monocyte/macrophage populations with Theileria annulato and Theileria parva. Vet Immunol Immunopathol 1989, 22:355-368.

2. Bogdan C, Röllinghoff M: How do protozoan parasites survive inside macrophages? Parasitol Today 1999, 15:22-28.

3. McGuire K, Glass Ej: The expanding role of microarrays in the investigation of macrophage responses to pathogens. Vet Immunol Immunopathol 2005, 105:259-275.

4. Chitko-McKown CG, Fox JM, Miller LC, Heaton MP, Bono JL, Keen JE, Grosse WM, Laegreid WW: Gene expression profiling of bovine macrophages in response to Escherichia coli 0157:H7 lipopolysaccharide. Dev Comp Immunol 2004, 28:635-645.

5. Weiss DJ, Evanson OA, Deng M, Abrahamsen MS: Gene expression and antimicrobial activity of bovine macrophages in response to Mycobacterium avium subsp. paratuberculosis. Vet Pathol 2004, 41:326-337.

6. Weiss DJ, Evanson OA, Deng MQ, Abrahamsen MS: Sequential patterns of gene expression by bovine monocyte-derived macrophages associated with ingestion of mycobacterial organisms. Microb Pathogenesis 2004, 37:215-224.

7. Werling D, Ruryk A, Heaney J, Moeller E, Brownlie J: Ability to differentiate between cp and ncp BVDV by microarrays: Towards an application in clinical veterinary medicine? Vet Immunol Immunopathol 2005, 108:157-164.

8. Wedlock DN, Kawakami RP, Koach J, Buddle BM, Collins DM: Differences of gene expression in bovine alveolar macrophages infected with virulent and attenuated isogenic strains of Mycobacterium bovis. Int Immunopharmacol 2006, 6:957-96I.

9. Staudt LM, Brown PO: Genomic views of the immune system. Annu Rev Immunol 2000, 18:829-859.
10. Wells C, Ravasi T, Sultana R, Yagi K, Carninci P, Bono H, Faulkner G, Okazaki Y, Quackenbush J, Hume DA, Lyons PA: Continued discovery of transcriptional units expressed in cells of the mouse mononuclear phagocyte lineage. Genome Res 2003, 13:1360-1365.

II. Kawai J, Shinagawa A, Shibata K, Yoshino M, Itoh M, Ishii Y, Arakawa T, Hara A, Fukunishi Y, Konno H, Adachi J, Fukuda S, Aizawa K, Izawa M, Nishi K, Kiyosawa H, Kondo S, Yamanaka I, Saito T, Okazaki Y, Gojobori T, Bono H, Kasukawa T, Saito R, Kadota K, Matsuda H, Ashburner M, Batalov S, Casavant T, Fleischmann W, Gaasterland T, Gissi C, King B, Kochiwa H, Kuehl P, Lewis S, Matsuo Y, Nikaido I, Pesole G, Quackenbush J, Schriml LM, Staubli F, Suzuki R, Tomita M, Wagner L, Washio T, Sakai K, Okido T, Furuno M, Aono H, Baldarelli R, Barsh G, Blake J, Boffelli D, Bojunga N, Carninci P, de Bonaldo MF, Brownstein MJ, Bult C, Fletcher C, Fujita M, Gariboldi M, Gustincich S, Hill D, Hofmann M, Hume DA, Kamiya M, Lee NH, Lyons P, Marchionni L, Mashima J, Mazzarelli J, Mombaerts P, Nordone P, Ring B, Ringwald M, Rodriguez I, Sakamoto N, Sasaki H, Sato K, Schonbach C, Seya T, Shibata Y, Storch KF, Suzuki H, Toyo-oka K, Wang KH, Weitz C, Whittaker C, Wilming L, Wynshaw-Boris A, Yoshida K, Hasegawa Y, Kawaji H, Kohtsuki S, Hayashizaki Y: Functional annotation of a full-length mouse cDNA collection. Nature 200I, 409:685-690.

12. Okazaki $Y$, Furuno M, Kasukawa T, Adachi J. Bono H, Kondo $S$ Nikaido I, Osato N, Saito R, Suzuki H, Yamanaka I, Kiyosawa H, Yagi K, Tomaru Y, Hasegawa Y, Nogami A, Schonbach C, Gojobori T, Baldarelli R, Hill DP, Bult C, Hume DA, Quackenbush J, Schriml LM, Kanapin A, Matsuda H, Batalov S, Beisel KW, Blake JA, Bradt D, Brusic V, Chothia C, Corbani LE, Cousins S, Dalla E, Dragani TA, Fletcher CF, Forrest A, Frazer KS, Gaasterland T, Gariboldi M, Gissi C, Godzik A, Gough J, Grimmond S, Gustincich S, Hirokawa N, Jackson IJ, Jarvis ED, Kanai A, Kawaji H, Kawasawa Y, Kedzierski RM, King BL, Konagaya A, Kurochkin IV, Lee Y, Lenhard B, Lyons PA, Maglott DR, Maltais L, Marchionni L, McKenzie L, Miki H, Nagashima T, Numata K, Okido T, Pavan W], Pertea G, Pesole G, Petrovsky N, Pillai R, Pontius JU, Qi D, Ramachandran S, Ravasi T, Reed JC, Reed DJ, Reid J, Ring BZ, Ringwald M, Sandelin A, Schneider C, Semple CA, Setou M, Shimada K, Sultana R, Takenaka Y, Taylor MS, Teasdale RD, Tomita M, Verardo R, Wagner L, Wahlestedt C, Wang Y, Watanabe Y, Wells C, Wilming LG, Wynshaw-Boris A, Yanagisawa M, Yang I, Yang L, Yuan Z, Zavolan M, Zhu Y, Zimmer A, Carninci P, Hayatsu N, HirozaneKishikawa T, Konno H, Nakamura M, Sakazume N, Sato K, Shiraki T, Waki K, Kawai J, Aizawa K, Arakawa T, Fukuda S, Hara A, Hashizume W, Imotani K, Ishii Y, Itoh M, Kagawa I, Miyazaki A, Sakai K, Sasaki D, Shibata K, Shinagawa A, Yasunishi A, Yoshino M, Waterston R, Lander ES, Rogers J, Birney E, Hayashizaki Y: Analysis of the mouse transcriptome based on functional annotation of 60,770 fulllength cDNAs. Nature 2002, 420:563-573.

13. Jensen K, Speed D, Paxton E, Williams JL, Glass E): Construction of a normalized Bos taurus and Bos indicus macrophage specific cDNA library. Anim Genet 2006, 37:75-77.

14. Iseli C, Jongeneel CV, Bucher P: ESTScan: a program for detecting, evaluating, and reconstructing potential coding regions in EST sequences. P Int Conf Intell Syst Mol Biol 1999:138-148.

15. ESTScan [http://www.ch.embnet.org/software/ESTScan.html]

16. Smith TP, Grosse WM, Freking BA, Roberts AJ, Stone RT, Casas E, Wray JE, White J, Cho J, Fahrenkrug SC, Bennett GL, Heaton MP, Laegreid WW, Rohrer GA, Chitko-McKown CG, Pertea G, Holt I, Karamycheva S, Liang F, Quackenbush J, Keele JW: Sequence evaluation of four pooled-tissue normalized bovine cDNA libraries and construction of a gene index for cattle. Genome Res 2001, II:626-630.

17. Sonstegard TS, Capuco AV, White J, Van Tassell CP, Connor EE, Cho J, Sultana R, Shade L, Wray JE, Wells KD, Quackenbush J: Analysis of bovine mammary gland EST and functional annotation of the Bos taurus gene index. Mamm Genome 2002, 13:373-379.

18. ARK-Genomics Centre for Functional Genomics in Farm Animals [http://www.ark-genomics.org]

19. Brazma A, Parkinson H, Sarkans U, Shojatalab M, Vilo J, Abeygunawardena N, Holloway E, Kapushesky M, Kemmeren P, Lara GG, Oezcimen A, Rocca-Serra P, Sansone S: ArrayExpress - a public repository for microarray gene expression data at the EBI. Nucleic Acids Res 2003, 31:68-71.

20. ArrayExpress [http://www.ebi.ac.uk/arrayexpress]

21. Tempelman RJ: Assessing statistical precision, power and robustness of alternative experimental designs for two col- 
our microarray platforms based on mixed effects models. Vet Immunol Immunopathol 2005, 105: 175-186.

22. Yao J, Burton JL, Saama P, Sipkovsky S, Coussens PM: Generation of EST and cDNA microarray resources for the study of bovine immunobiology. Acta Vet Scand 200I, 42:39I-405.

23. Hill EW, O'Gorman GM, Agaba M, Gibson JP, Hanotte O, Kemp SJ, Naessens J, Coussens PM, MacHugh DE: Understanding bovine trypanosomiasis and trypanotolerance: the promise of functional genomics. Vet Immunol Immunopathol 2005, 105:247-258.

24. Tao W, Mallard BA, Karrow N, Bridle B: Construction and application of a bovine immune-endocrine cDNA microarray. Vet Immunol Immunopathol 2004, I0 I:I-I7.

25. Donaldson L, Vuocolo T, Gray C, Strandberg Y, Reverter A, McWilliam S, Wang YH, Byrne K, Tellam R: Construction and validation of a bovine innate immune microarray. BMC Genomics 2005 , 6:135.

26. Band MR, Olmstead C, Everts RE, Liu ZL, Lewin HA: A 3800 gene microarray for cattle functional genomics: comparison of gene expression in spleen, placenta, and brain. Anim Biotechnol 2002, 13:163-172

27. Gao JJ, DiesI V, Wittmann T, Morrison DC, Ryan JL, Vogel SN, Follettie MT: Bacterial LPS and CpG DNA differentially induce gene expression profiles in mouse macrophages. J Endotoxin Res 2003, 9:237-243.

28. Nau GJ, Richmond JFL, Schlesinger A, Jennings EG, Lander ES, Young RA: Human macrophage activation programs induced by bacterial pathogens. P Natl Acad Sci USA 2002, 99: I503-I 508.

29. Chaussabel D, Semnani RT, McDowell MA, Sacks D, Sher A, Nutman TB: Unique gene expression profiles of human macrophages and dendritic cells to phylogenetically distinct parasites. Blood 2003, I 02:672-68I.

30. Wang Y, Barbacioru C, Hyland F, Xiao W, Hunkapiller KL, Blake J, Chan F, Gonzalez C, Zhang L, Samaha RR: Large scale real-time $P C R$ validation on gene expression measurements from two commercial long-oligonucleotide microarrays. BMC Genomics 2006, 7:59.

31. Evertsz EM, Au-Young J, Ruvolo MV, Lim AC, Reynolds MA: Hybridization cross-reactivity within homologous gene families on glass cDNA microarrays. Biotechniques 200 I, 3 I: I I82-I I 92.

32. Patel OV, Suchyta SP, Sipkovsky SS, Yao J, Ireland J], Coussens PM, Smith GW: Validation and application of a high fidelity mRNA linear amplification procedure for profiling gene expression. Vet Immunol Immunopathol 2005, 105:33 I-342.

33. Rouzaut A, Lopez-Moratalla N, de Miguel C: Differential gene expression in the activation and maturation of human monocytes. Arch Biochem Biophys 2000, 374:153-160.

34. Zhou AQ, Herriott MJ, Leu RW: Kinetics of the biosynthesis of complement subcomponent $\mathrm{Clq}$ by murine macrophages: LPS, immune complexes, and zymosan alone and in combination with interferon-gamma. J Leukocyte Biol |991, 50:453-463.

35. Dürig J, Giese A, Schulz-Schaeffer W, Rosenthal C, Schmücker U, Bieschke J, Dührsen U, Kretzschmar HA: Differential constitutive and activation-dependent expression of prion protein in human peripheral blood leucocytes. $\mathrm{Br}$ J Haematol 2000 , I 08:488-496.

36. de Almeida CJG, Chiarini LB, da Silva JP, e Silva PMR, Martins MA, Linden R: The cellular prion protein modulates phagocytosis and inflammatory response. / Leukocyte Biol 2005, 77:238-246.

37. Burthem J, Urban B, Pain A, Roberts DJ: The normal cellular prion protein is strongly expressed by myeloid dendritic cells. Blood 200I, 98:3733-3738

38. Sun Y, Leaman DW: Involvement of noxa in cellular apoptotic responses to interferon, double-stranded RNA, and virus infection. J Biol Chem 2005, 280: I556I-I5568.

39. Bogerd HP, Wiegard HL, Doehle BP, Lueders KK, Cullen BR: APOBEC3A and APOBEC3B are potent inhibitors of LTRretrotransposan function in human cells. Nucleic Acids Res 2006 , 34:89-95.

40. Scheibenbogen C, Keiholz U, Richter M, Andreesen R, Hunstein W: The interleukin-2 receptor in human monocytes and macrophages: regulation of expression and release of the alpha and beta chains (p55 and p75). Res Immunol 1992, 143:33-37.

41. Dekkers PEP, Juffermans NP, ten Hove $T$, de Jonge $E$, van Deventer $\mathrm{SJ} \mathrm{H}$, van der Poll T: Endotoxin down-regulates monocyte and granulocyte interleukin-6 receptors without influencing gp I30 expression in humans. J Infect Dis 2000, 18 I: I055-106I.

42. Parker LC, Whyte MKB, Vogel SN, Dower SK, Sabroe I: Toll-like receptor (TLR) 2 and TLR4 agonists regulate CCR expression in human monocytic cells. J Immunol 2004, I72:4977-4986.

43. Grey ST, Tsuchida A, Hau H, Orthner CL, Salem HH, Hancock WW: Selective inhibitory effects of the anticoagulant activated protein $\mathbf{C}$ on the responses of human mononuclear phagocytes to LPS, IFN- $\gamma$, or phorbol ester. J Immunol 1994, 153:3664-3672.

44. Pei L, Castrillo A, Chen M, Hoffmann A, Tontonoz P: Induction of NR4A orphan nuclear receptor expression in macrophages in response to inflammatory stimuli. J Biol Chem 2005, 280:29256-29262.

45. Begum NA, Kobayashi M, Moriwaki Y, Matsumoto M, Toyoshima K, Seya T: Mycobacterium bovis BCG cell wall and lipopolysaccharide induce a novel gene, BIGMI03, encoding a 7-TM protein: identification of a new protein family having $\mathrm{Zn}$ transporter and Zn-metalloprotease signatures. Genomics 2002, 80:630-645.

46. Rozen S, Skaletsky HJ: Primer3 on the WWW for general users and for biologist programmers. In Bioinformatics Methods and Protocols: Methods in Molecular Biology Edited by: Krawetz S, Misener S. Totowa: Humana Press; 2000:365-386.

\begin{tabular}{l} 
47. Primer3 [http://frodo.wi.mit.edu/cgi-bin/primer3/ \\
\hline
\end{tabular} primer3 www.cgi]

48. Brooke GP, Parsons KR, Howard CJ: Cloning of two members of the SIRP $\alpha$ family of protein tyrosine phosphatase binding proteins in cattle that are expressed on monocytes and a sub-population of dendritic cells and which mediate binding to CD4 T cells. Eur J Immunol I998, 28: I-II.

49. Smyth GK: Limma: linear models for microarray data. In Bioinformatics and Computational Biology Solutions using R and Bioconductor Edited by: Gentleman R, Carey V, Dudoit S, Irizarry R, Huber. New York: Springer; 2005:397-420.

50. Smyth GK, Speed TP: Normalization of CDNA microarray data. Methods 2003, 3I:265-273.

5I. Baird D, Johnstone P, Wilson T: Normalization of microarray data using a spatial mixed model analysis which includes splines. Bioinformatics 2004, 20:3196-3205.

52. Smyth GK: Linear models and empirical Bayes methods for assessing differential expression in microarray experiments. Statistical Applications in Genetics and Molecular Biology 2004, 3(I):. Article 3

53. Benjamini $Y$, Hochberg $Y$ : Controlling the false discovery rate: a practical and powerful approach to multiple testing. J Roy Stat Soc B Met 1995, 57:289-300.

54. NetPrimer [http://www.premierbiosoft.com/netprimer/netpr launch/netprlaunch.html]

55. Pfaffl MW: A new mathematical model for relative quantification in real-time RT-PCR. Nucleic Acids Res 200I, 29:e45.

\begin{tabular}{l} 
56. Roslin Institute [http://www.roslin.ac.uk/about/staff/ \\
\hline
\end{tabular} Bovine Macrophage cDNA Microarray.xls]

Publish with Bio Med Central and every scientist can read your work free of charge

"BioMed Central will be the most significant development for disseminating the results of biomedical research in our lifetime. "

Sir Paul Nurse, Cancer Research UK

Your research papers will be:

- available free of charge to the entire biomedical community

- peer reviewed and published immediately upon acceptance

- cited in PubMed and archived on PubMed Central

- yours - you keep the copyright 